\title{
New leptolycines from Ecuador and Peru (Coleoptera: Lycidae)
}

\section{Новые лептолищины из Эквадора и Перу (Coleoptera: Lycidae)}

\author{
Sergey V. Kazantsev \\ C.В. Казанцев
}

Insect Centre, Donetskaya 13-326, Moscow 109651, Russia. E-mail: kazantss@mail.ru Инсект-центр, ул. Донецкая 13-326, Москва 109651, Россия.

KEY WORDS: Coleoptera, Lycidae, Leptolycinae, taxonomy, synonymy, new genera, new species, Neotropical region.

КЛЮЧЕВЫЕ СЛОВА: Coleoptera, Lycidae, Leptolycinae, таксономия, синонимия, новые рода, новые виды, Неотропическая область.

ABSTRACT. Four new genera, Andepteron gen.n., Aplopteron gen.n., Ceratolycus gen.n. and Petrovia gen.n., and nineteen new species of leptolycine netwinged beetles: Andepteron bolivari, A. nubile, Aplopteron yasuniense, Cephalolycus cajanumaensis, C. pichinchensis, Ceratolycus victoriae, Ceratoprion alexi, $C$. diosense, $C$. loretense, Flabellocaenia iquitosensis, $F$. ocopensis, F. pastazensis, F. tiputiniensis, Petrovia clavicula, Prioceraton calabazense, P. tishechkini, Pseudacroleptus aleksandri, P. orellanus and Tishechkinia petrovi spp.n. - are described from Ecuador and Peru. Cephalolycus Pic, 1926 and Flabellolycinella Kleine, 1941 are transferred from Calopterini (Lycinae) to Leptolycini (Leptolycinae). Flabellolycinella Kleine, 1941, syn.n. is put in synonymy with Pseudacroleptus Pic, 1911. Keys to leptolycine genera and species of Ecuador and Peru are provided.

РЕЗЮМЕ. Из Эквадора и Перу описывается четыре новых рода, Andepteron gen.n., Aplopteron gen.n., Ceratolycus gen.n. и Petrovia gen.n., и девятнадцать новых видов жуков-краснокрылов трибы Leptolycini: Andepteron bolivari, A. nubile, Aplopteron yasuniense, Cephalolycus cajanumaensis, $C$. pichinchensis, Ceratolycus victoriae, Ceratoprion alexi, C. diosense, C. loretense, Flabellocaenia iquitosensis, F. ocopensis, F. pastazensis, F. tiputiniensis, Petrovia clavicula, Prioceraton calabazense, $P$. tishechkini, Pseudacroleptus aleksandri, P. orellanus and Tishechkinia petrovi spp.n. Cephalolycus Pic, 1926 и Flabellolycinella Kleine, 1941 переносятся из Calopterini (Lycinae) в Leptolycini (Leptolycinae). Flabellolycinella Kleine, 1941, syn.n. сводится в синонимы к Pseudacroleptus Pic, 1911. Приводится определительная таблица родов и таблицы видов лептолицин Эквадора и Перу.

\section{Introduction}

Until recently only one species of the subfamily Leptolycinae of net-winged beetles had been reported from Ecuador and Peru [Kleine, 1933; 1941; Black- welder, 1945]. It was Flabellolycinella crocea Kleine, 1941 , known just from one specimen. Though treated as a member of Calopterini (Lycinae) by the author [Kleine, 1941], the genus Flabellolycinella Kleine, 1941 was, as its description suggested, very close (if not synonymic) to Pseudacroleptus Pic, 1911, a member of Leptolycinae Leng et Mutchler, 1922, with which it had not been compared. Another two representatives of the group, Neolyrium carltoni Kazantsev, 2005 and Pseudacroleptus gorgonus Kazantsev, 2013, were described not so long ago from Ecuador (the former) and Peru (the latter) [Kazantsev, 2005, 2013].

An opportunity to study the rich Lycidae material collected in this region of eastern South America recently, especially during the 1999 and 2005-2015 expeditions of Dr. A. Petrov to Peru, and expeditions of Louisiana State University Arthropod Museum, Dr. A. Tishechkin and Moscow Insect Centre to Ecuador, allows to make a further contribution to the knowledge of these little known beetles. Despite the fact that the number of papers devoted to leptolycines has been on the rise of late [Bocák, 2001; Kazantsev, 2005, 2009, 2012, 2013; Kazantsev, Zaitsev, 2009; Ferreira, Ivie, 2016], it has not led to considerable progress in understanding their biology and life history, and their diversity does not appear to be satisfactorily studied either. Although the lineage was specifically targeted in the course of preparation of a $\mathrm{PhD}$ thesis [Miller, 1991], nothing of its results unfortunately has ever been published.

Nineteen new species of Leptolycinae from Ecuador and Peru are described below, which brings the number of leptolycines known from these two countries to twenty two. Five of the nineteen new species turned out to belong in four yet undescribed genera, the remaining fourteen representing the genera Cephalolycus Pic, 1926, Ceratoprion Gorham, 1884, Flabellocaenia Pic, 1929, Prioceraton Kazantsev, 2013, Pseudacroleptus Pic, 1911 and Tishechkinia Kazantsev, 2013. The aforementioned Flabellolycinella Kleine, 1941 was found to be synonymous with Pseudacroleptus. 


\section{Material and Methods}

The studied specimens were pinned or glued on cardboard plates. For a detailed examination they were relaxed in water; then the detached ultimate abdominal segments were treated for several hours in $10 \% \mathrm{KOH}$ at room temperature, then, with the extracted genitalia, placed in microvials with glycerin; or, glued back on cardboard plates.

MSP-1 zoom stereoscopic dissecting microscope with $\mathrm{x} 8-\mathrm{x} 80$ and Micromed-2/3-20 zoom stereoscopic light microscope with $\mathrm{x} 100-\mathrm{x} 400$ magnification range were used. Photographs were taken with Canon EOS 6D camera.

The following acronyms are used in the paper: ICM - Insect Center, Moscow; LSAM - Louisiana State University Arthropod Museum, Baton Rouge.

\section{Taxonomy}

Leptolycinae Leng et Mutchler, 1922

Leptolycini Leng et Mutchler, 1922

type genus Leptolycus Leng et Mutchler, 1922.

DISTRIBUTION. South America.

REMARKS. The leptolycines are quite easily separated from other net-winged beetles by the reduced to rudiments mandibles, reduced labrum and reduced and peculiarly modified labium, as well as by the narrow, not bilobed tarsi, including the penultimate tarsomere. Another feature of the leptolycines, although shared by some calopterines [e.g., Nascimento \& Bocakova, 2009], is the conspicuous lack of any information on their females, most probably due to the fact that they are larviform and completely different in behaviour and perhaps life history. All leptolycine genera reported from the continental South America have been found in Ecuador and Peru, except Neolyrium Kazantsev, 2005, registered only in Venezuela and French Guyana [Kazantsev, 2005; Constantin, 2010].

\section{A key to genera of Leptolycini of Ecuador and Peru}

1. Antennae 10-segmented (Figs 87-88)

Tishechkinia Kazantsev, 2013

- Antennae 11-segmented (e.g., Figs 1, 14) ................. 2

2. Antennomere 3 (or its stem, if flabellate) subequal in length to pedicel (e.g., Figs 32, 54) ...................... 3

- Antennomere 3 considerably larger and longer than pedicel (e.g., Figs 1, 14).

3. Antennomere 3, as well as antennomeres 4-10, flabellate (e.g., Figs 78, 82) ............. Pseudacroleptus Pic, 1911

- Antennomere 3 without flabellum (e.g., Figs 32, 70). 4

4. Aedeagus slender and elongate, with narrow elongate median lobe and short parameres (e.g., Figs 34-35, 7273)

- Aedeagus short and robust, parameres subequal in length to median lobe (e.g., Figs 42-43, 65-66) ................... 6

5. Antennomeres 4-10 strongly dentate or flabellate; elytra reticulate (Figs 32, 36). Spiculum gastrale not widened proximally; paraproct divided by median suture (Figs 33, 37) .................................... Cephalolycus Pic, 1926

- Antennomeres 4-10 almost parallel-sided; elytra granulose (Figs 70, 74). Spiculum gastrale proximally widened; paraproct not divided by median suture (Figs 71, 75)...

Prioceraton Kazantsev, 2013
6. Antennomeres 4-10 dentate (e.g., Figs 40, 43). Trochanters relatively short, semi-triangular. Parameres free (e.g., Figs 42, 51) .................... Ceratoprion Gorham, 1884

- Antennomeres 4-10 flabellate (Figs 53-56). Trochanters long and narrow, cylindric. Parameres tubular (e.g., Figs $58,65)$ Flabellocaenia Pic, 1929

7. Antennomeres 3-10 dentate; elytra mostly bicostate, finely irregularly areolate or granulose (Figs 14, 20) ...... 8

- Antennomeres 3-10 almost parallel-sided; elytra subquadricostate, reticulate, with large, relatively regular cells in interstices (Figs 1, 10, 26)

8. Labium with elongate prementum and one-segment palps (Fig. 16). Prosternum triangular, relatively long (Fig. 15). Pro- and mesocoxae considerably less elongate (Fig. 15). Ultimate sternite with conspicuously widened posteriorly proximal process (Fig. 17). Aedeagus without parameres; phallobase long and tubular, open proximally (Figs 1819)

Aplopteron gen.n.

- Labium reduced to miniature one-segment palps (Fig. 22). Prosternum Y-shaped, short (Fig. 21). Pro- and mesocoxae considerably more elongate (Fig. 21). Ultimate sternite with slightly widened posteriorly spiculum gastrale (Fig. 23). Aedeagus with parameres; phallobase relatively short and closed proximally (Figs 24-25) ........ Ceratolycus gen.n.

9. Head ventrally medially emarginate at posterior margin (Figs 2-3). Ultimate labial palpomere broad (Fig. 4). Pronotum with conspicuous median keel; elytra almost glabrous (Figs 1, 10). Trochanters long, cylindric (Fig. 2). Spiculum gastrale proximally widened, symmetric (Figs 7, 11). Aedeagus relatively robust, with relatively short median lobe and elongate parameres (Figs 8-9, 12-13)....

Andepteron gen.n.

- Head ventrally straight at posterior margin (Fig. 27). Ultimate labial palpomere narrow, pointed at apex (Fig. 28). Pronotum with obscure median areole; elytra hairy (Fig. 26). Trochanters relatively short, semi-triangular. Spiculum gastrale proximally narrowed, asymmetric (Fig. 29). Aedeagus slender, with elongate median lobe and short parameres (Figs 30-31).

Petrovia gen.n.

\section{Andepteron Kazantsev, gen.n.}

Type species: Andepteron bolivari sp.n.

DESCRIPTION. Male. Alate, slender, elongate (Fig. 1). Head square, moderately narrowed behind eyes, ventrally conspicuously medially concave at posterior margin (Fig. 3). Fastigium acute, ca. 45 degrees. Eyes spherical. Labrum reduced, lightly sclerotized, lying inside epistoma. Mandibles vestigial. Maxillary palps slender, narrow, 4-segmented, with ultimate palpomere pointed distally. Labium consisting of mentum, non-paired prementum and a pair of two-segmented palps (Figs 2-4). Gula absent (Fig. 3). Antennal prominence conspicuous, antennal sockets separated by minute lamina. Antenna 11-segmented, long, from antennomere 3 flattened; antennomere 2 short, transverse, more than five times shorter than antennomere 3; antennomeres 3-11 subparallel-sided; antennal pubescence short, dense and decumbent (Figs 1-2).

Pronotum small, more than 8 times shorter than elytra, with conspicuous median keel provided with miniature narrow groove in posterior half; posterior angles conspicuously produced laterally (Fig. 1). Prosternum short, Y-shaped (Fig. 2). Thoracic spiracles elongate, not hooded, slightly projecting beyond coxae. Mesonotum with scutellum not attaining to anterior margin; scutellum with narrow elongate postnotal projections (Fig. 5). Mesoventrite subquadrate, not divided by median suture, attached to mesepisternum with additional 




Figs 1-13. General view and details of Andepteron gen.n., male holotypes: $1-9-$ A. bolivari sp.n.; 10-13 - A. nubile sp.n.; 1, 10 general view; 2 - anterior part of body; 3 - head; 4 - labium; 5 - mesonotum; 6 - meso- and metaventrite; 7,11 - ultimate abdominal segments; 8-9, 12-13 - aedeagus; $1,5,7,10-11$ - dorsally; 2-4, 6, 8, 12 - ventrally; 9, 13 - laterally. Scales: 0.5 mm.

Рис. 1-13. Общий вид и детали строения Andepteron gen.n., голотипы, самцы: 1-9 - A. bolivari sp.n.; 10-13 - A. nubile sp.n.; 1,10 - общий вид; 2 - передняя часть тела; 3 - голова; 4 - нижняя губа; 5 - среднеспинка; 6 - мезо- и метавентрит; 7,11 вершинные сегменты брюшка; 8-9, 12-13 - эдеагус; 1, 5, 7, 10-11 - сверху; 2-4, 6, 8, 12 - снизу; 9, 13 - сбоку. Масштабные линейки: 0,5 мм. 
sclerite; mesepimeron ca. 2 times shorter than mesepisternum and noticeably extending beyond its base (Fig. 6). Elytra long, widening distally, dehiscent in distal third, completely covering wings, with three fully developed primary costae $(1$, 2 and 4 ) and costa 3 noticeably reduced; interstices with large elongate cells; elytral pubescence extremely short and scarce (Fig. 1). Metanotum subquadrate, slightly widening anteriorly, with straight narrow scuto-scutellar suture subequal in length to allocrista; prescutum with median suture; intrascutal suture small, short, emerging at ca. half of scutum and not going beyond allocrista; scutellum with obscure median suture; postnotal plate short, without median suture. Metaventrite elongate, with acute, pointed posterior angles; discrimen complete, attaining to mesosternum; metendosternite simple, ca. 0.35 length of metaventrite, with short lateral arms and inconspicuous transverse suture (Fig. 6). Metathoracic wing with fringe of short hairs; anal cell closed, wedge cell absent, $\mathrm{Cu}$ veins bifurcate; cu-a brace absent.

Protrochantins narrow, similar to mesotrochantins. Proand mesocoxae elongate; metacoxae separated, with complete meral suture. Legs long, narrow and slender; trochanters elongate, narrow, cylindrical, hind trochanters ca. 1.8 times shorter than femurs, connected to femurs distally; femurs and tibiae flattened, straight, slightly widened distally, tibial spurs minute, straight and narrow; tarsomeres 1-4 narrow, without plantar pads; all claws simple (Fig. 1).

Abdominal spiracles minute, located at the very edge of sternites. Paraproct not divided by median suture (divided by median suture in A. nubile sp.n., Fig. 11); sternite 9 with short, widened and rounded proximally spiculum gastrale (Fig. 7).

Aedeagus symmetric, relatively robust, with elongate parameres and elongate, almost parallel-sided median lobe; parameral apices rounded; phallobase without median suture (Figs 8-9) form.

Female. Unknown, probably paedomorphic and larvi-

BIOLOGY. All specimens of the two species of Andepteron gen.n. described below were collected in a cloud forest at $1300-2900 \mathrm{~m}$ above sea level.

ETYMOLOGY. The name of the genus is derived from "the Andes", the name of the mountain chain in South America, where the two members of the genus have been collected, and the Greek for "wing". Gender neutral.

DIAGNOSIS. Andepteron gen.n. may be differentiated from other leptolycine net-winged beetles by the combination of the two-segment labial palps (Fig. 4), pronotal structure with conspicuous median keel, noticeably widened posteriorly elytra (Figs 1, 10), long and cylindric trochanters (Fig. 2), widened proximally ultimate sternite (Figs 7, 11) and relatively robust aedeagus, with relatively short median lobe and elongate parameres (Figs 8-9, 12-13).

The structure of the aedeagus in Andepteron gen.n. is fairly similar to that of the calopterine genus Lycomorphon Pic, 1922 [Nascimento, Bocakova, 2009], suggesting possible relationships of some current leptolycines, including Andepteron gen.n., with Calopterini.

REMARKS. Only two species are known in this genus, both from Ecuador.

DISTRIBUTION. Ecuador.

A Key to SPECIES OF ANDEPTERON GEN.N. OF ECUADOR AND PERU

1. Antennae with three ultimate segments orange yellow; elytra noticeably widened distally, with two orange testaceous bands; aedeagus shorter (Figs 1, 8-9)

A. bolivari sp.n.
- Antennae with two ultimate segments orange yellow; elytra little widened distally, with pair of posterior orange testaceous spots; aedeagus more elongate (Figs 10, 1213) A. nubile sp.n.

\section{Andepteron bolivari Kazantsev, sp.n.}

Figs 1-9.

MATERIAL: Holotype, $\sigma^{7}$, Ecuador: Pichincha, env. Mindo, 1300-1600 m, cloud forest, 18-24.VII.2016, S. Kazantsev leg. (ICM); paratypes: $\sigma^{7}$, same label; $2 \sigma^{7} \sigma^{2}$, Ecuador: Pichincha, 50 $\mathrm{km}$ E S. Domingo, $1600 \mathrm{~m}$, cloud forest, 9-10.VII.2016, S. \& S. Kazantsev leg. (ICM).

DESCRIPTION. Male. Black; antennomere 2 and labial palpomere 1 light brown; antennomeres 9-11, pronotal sides, elytra, except discal and apical bands and suture in proximal fourth, trochanters and tarsomeres 5 orange testaceous.

Vertex densely punctate, with shallow transverse impression and narrow median keel behind antennal prominence. Eyes moderately large, interocular distance ca. 1.3 times greater than eye diameter. Maxillary palps small, slender, ultimate palpomeres elongate, pointed distally. Antennae attaining to elytral five sixths; antennomere $3 \mathrm{ca}$. 8.5 times longer than antennomere 2 and ca. 1.1 times shorter than antennomere 4 (Fig. 1).

Pronotum transverse, ca. 1.8 times as wide as long, trapezoidal, bisinuate basally and rounded anteriorly, with strongly produced latero-posteriorly posterior and blunt anterior angles (Fig. 1). Scutellum elongate, slightly widening distally, deeply emarginate at apex (Fig. 5).

Elytra narrow, long, ca. 3.9 times longer than wide at humeri, widening distally, with prominent, equally developed primary costae 1, 2 and 4 (Fig. 1).

Paraproct not divided by median suture (Fig. 7). Aedeagus relatively short; parameres attaining to ca. 0.55 of median lobe; phallobase ca. 0.3 length of median lobe (Figs 8-9).

Female. Unknown.

Length: $6.2-6.8 \mathrm{~mm}$. Width (humerally): $1.4-1.6 \mathrm{~mm}$.

ETYMOLOGY. The new species is named after Simón Bolívar, a Latin American leader who played a key role in the establishment of Bolivia, Colombia, Ecuador, Peru, Venezuela and Panama as sovereign states.

DIAGNOSIS. Andepteron bolivari sp.n. can be separated from $A$. nubile sp.n. by the coloration, noticeably more widened posteriorly elytra and somewhat less elongate aedeagus (Figs 1, 8-9).

DISTRIBUTION. Known only from the Andes in Ecuador

Andepteron nubile Kazantsev, sp.n. Figs 10-13.

MATERIAL: Holotype, $\sigma^{7}$, Ecuador: Pichincha, 15-20 km WNW Calacali, 2900 m, cloud forest, 16.VII.2016, S. Kazantsev leg. (ICM).

DESCRIPTION. Male. Black; antennomeres 10-11 and elytral postdiscal spots orange testaceous.

Vertex densely punctate, with shallow transverse impression and narrow median keel behind antennal prominence. Eyes small, interocular distance ca. 2.2 times greater than eye diameter. Maxillary palps small, slender, ultimate palpomeres elongate, pointed distally. Antennae attaining to elytral four fifths; antennomere 3 ca. 5.5 times longer than antennomere 2 and ca. 1.1 times shorter than antennomere 4 (Fig. 10).

Pronotum transverse, almost 2 times as wide as long, trapezoidal, with concave sides, bisinuate basally and somewhat rounded anteriorly, with strongly produced latero-posteriorly posterior and blunt rounded anterior angles (Fig. 10). Scutellum elongate, parallel-sided, deeply emarginate at apex (Fig. 10). 
Elytra narrow, long, ca. 4.6 times longer than wide at humeri, slightly widening distally, with prominent, equally developed primary costae 1, 2 and 4 (Fig. 1).

Paraproct divided by median suture (Fig. 11). Aedeagus relatively long; parameres attaining to ca. 0.6 of median lobe; phallobase ca. 0.5 length of median lobe (Figs 8-9).

Female. Unknown.

Length: $7.9 \mathrm{~mm}$. Width (humerally): $1.6 \mathrm{~mm}$.

ETYMOLOGY. The name of the new species is derived from the Latin for «cloudy», alluding the its discovery in a cloud forest.

DIAGNOSIS. Andepteron nubile sp.n. can be separated from A. bolivari sp.n., the only other known species of the genus, by the coloration, noticeably more parallel-sided elytra and somewhat more elongate aedeagus (Figs 10, 12-13)

DISTRIBUTION. Known only from the Andes in Ecuador.

\section{Aplopteron Kazantsev, gen.n.}

Type species: Aplopteron yasuniense sp.n.

DESCRIPTION. Male. Alate, slender, elongate (Fig. 14) Head square, only slightly narrowed behind eyes, ventrally with small triangular incision at posterior margin (Fig. 15) Fastigium acute, ca. 30 degrees. Eyes relatively small, flattened. Labrum reduced, lightly sclerotized, lying inside epistoma. Mandibles vestigial. Maxillary palps slender, 4-segmented, tapering and pointed apically (Fig. 15). Labium consisting of non-paired elongate prementum and a pair of one-segmented pointed at apex palps (Fig. 16). Gula absent. Antennal prominence conspicuous, antennal sockets separated by minute lamina. Antenna 11-segmented, long, from antennomere 3 flattened; antennomere 2 short, transverse, considerably shorter than antennomere 3; antennomeres 3-10 serrate; antennal pubescence short, dense and decumbent (Figs 14-15).

Pronotum small, more than 8 times shorter than elytra, with conspicuous narrow median keel with miniature narrow groove in the middle; posterior angles conspicuously produced laterally (Fig. 14). Prosternum relatively long, triangular (Fig. 15). Thoracic spiracles elongate, small, simple, not hooded, slightly protruding beyond coxae. Mesonotum with scutellum almost attaining to anterior margin; scutellum triangular, emarginate at apex. Mesoventrite subquadrate, not divided by median suture, attached to mesepisternum with additional sclerite; mesepimeron only slightly shorter than mesepisternum and slightly extending below its base (Fig. 15). Elytra long, widening distally, dehiscent in distal third, completely covering wings, with two fully developed primary costae (2 and 4); interstices densely granulose; elytral pubescence short and decumbent (Fig. 14). Metanotum transverse, scuto-scutellar ridge straight noticeably longer than allocrista; prescutum with median suture; intrascutal suture small, emerging at distal third of scutum; scutellum without median suture; postnotal plate short, without median suture. Metaventrite elongate, with acute, pointed posterior angles; discrimen complete, attaining to mesosternum. Metathoracic wing with fringe of short hairs; anal cell closed; wedge cell absent, $\mathrm{Cu}$ veins present; cu-a brace vestigial.

Protrochantins similar to mesotrochantins. Pro- and mesocoxae elongate; metacoxae narrowly separated. Legs moderately long; trochanters elongate, cylindrical, but relatively short, more than 2.5 times shorter than relevant femurs, connected to femora distally; femurs and tibiae flattened, straight, noticeably widened, tibial spurs miniature, not exceeding surrounding bristles in length and only slightly wider; tarsomeres 1-4 narrow, without plantar pads; all claws simple.

Abdominal spiracles located at the very edge of sternites. Paraproct deeply incised, not divided by median suture; sternite 9 with moderately long, conspicuously widened proximally spiculum gastrale (Fig. 17).

Aedeagus symmetric, slender, with absent parameres and elongate, narrow, constricted apically median lobe; phallobase tubular, considerably longer than median lobe (Figs 18-19).

Female. Unknown, probably paedomorphic and larviform.

BIOLOGY. All specimens of Aplopteron gen.n. were collected in the Amazon selva by flight intercept traps.

ETYMOLOGY. The name of the genus is derived from "aplos", the Greek for «simple», alluding to the structure of the aedeagus of its type species, and «pteron», the Greek for "wing". Gender neutral.

DIAGNOSIS. Aplopteron gen.n. is readily differentiated from other leptolycines by the the combination of the complete narrow median keel of the pronotum, granulose elytra (Fig. 14) triangular, relatively long prosternum (Fig. 15 ) and moderately long, proximally widened spiculum gastrale (Fig. 17). Its aedeagus lacks parameres and the phallobase is long and tubular, open proximally (Figs 1819). In the shape of the prosternum Aplopteron gen.n. somewhat resembles the antillean Dominopteron Kazantsev, 2013, easily distinguishable by the structure of the ultimate sternite and aedeagus (Figs 17-19). On the other hand, the new genus seems to approach the also antillean Nanolycus Kazantsev, 2013, possessing somewhat similar prosternum and male genital structure, at the same time being quite different in structure of the antennae and ultimate abdominal segments (Figs 14, 17).

REMARKS. Only one species is known in this genus.

DISTRIBUTION. Amazon basin, Ecuador.

\section{Aplopteron yasuniense Kazantsev, sp.n.} Figs 14-19.

MATERIAL: Holotype, $\sigma^{7}$, Ecuador: Orellana, Yasuni Res. Stn., FIT, 11-26.VII.2008, A. Tishechkin leg. (ICM); paratypes: 2 $\sigma^{7} \sigma^{2}$, same label (ICM); $\sigma^{7}$, Ecuador: Napo, Yasuni Res. Stn. on mid Rio Tiputini, $0^{\circ} 40.5^{\prime} \mathrm{S}, 7^{\circ} 24^{\prime} \mathrm{W}$, FIT, 28.VI-5.VII.1999, A. Tishechkin leg.; $\sigma^{7}$, Ecuador: Napo, Yasuni, Yasuni National Park, Yasuni Biological Station, $0^{\circ} 40^{\prime} 32^{\prime}$ 'S, $76^{\circ} 23^{\prime} 50^{\prime \prime} \mathrm{W}$, FIT, 2530.VII.1999, A. Tishechkin leg. (LSAM)

DESCRIPTION. Male. Dark brown; antennomere 2 and 11 , the latter except proximally, pronotal sides, elytral humeri, trochanters, bases of femurs and knees testaceous.

Vertex flat, shining, finely punctate, with two small roundish impressions behind antennal prominence. Eyes small, interocular distance about 2 times greater than eye diameter. Maxillary palps slender, ultimate palpomere miniature, pointed distally. Antennal sockets separated by narrow lamina. Antennae strongly flattened, feebly flabellate, attaining to elytral seven eighths; antennomere 3 ca. 10 times longer than antennomere 2 and ca. 1.25 times shorter than antennomere 4; antennomeres 3-11 with relatively short, sense, decumbent pubescence (Figs 14-15).

Pronotum transverse, ca. 1.8 times as wide as long, trapezoidal, conspicuously incised at sides, almost straight posteriorly and slightly produced forward anteriorly, with strongly laterally produced posterior and right anterior angles (Fig. 14). Scutellum elongate, parallel-sided, slightly emarginate at apex (Fig. 14).

Elytra narrow, long, ca. 3.4 times longer than wide at humeri, almost parallel-sided, with prominent, equally developed primary costae 2 and 4 (Fig. 14).

Spiculum gastrale almost as long ultimate sternite (Fig. 17). Aedeagus long and narrow, noticeably curved in lateral view; phallobase ca. 1.7 times longer than median lobe (Figs 18-19). 
Female. Unknown.

Length: $3.6-4.7 \mathrm{~mm}$. Width (humerally): $0.8-1.1 \mathrm{~mm}$.

ETYMOLOGY. The name of the new species is derived from the locality, where the type series was taken.

DIAGNOSIS. Aplopteron yasuniense sp.n. can be easily distinguished from other leptolycines by the generic characters, i.e., by the granulose elytra, relatively long triangular prosternum and its aedeagus without parameres and long tubular phallobase (Figs 14-19).

DISTRIBUTION. Amazon basin, Ecuador.
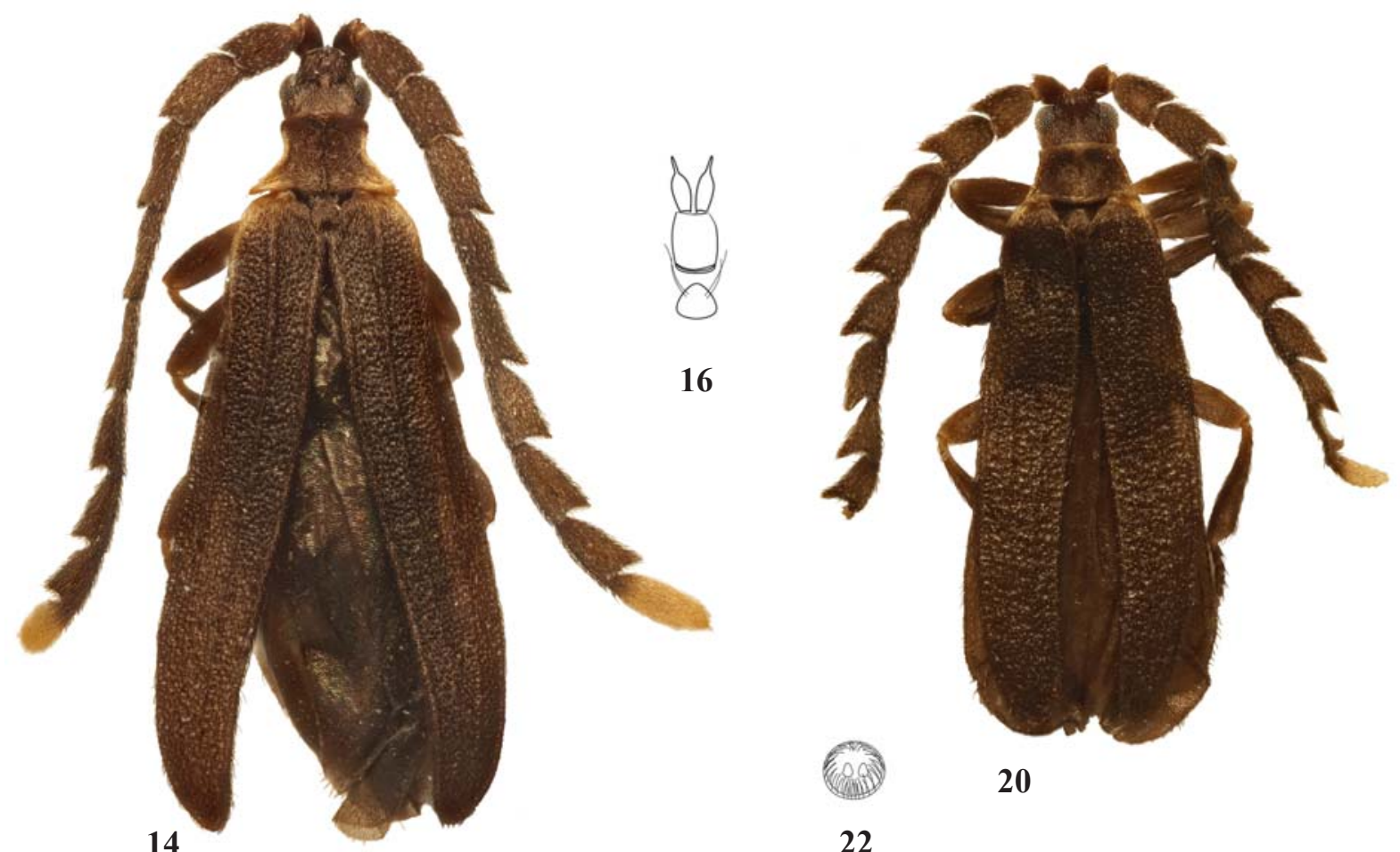

20

22

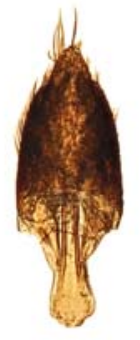

17
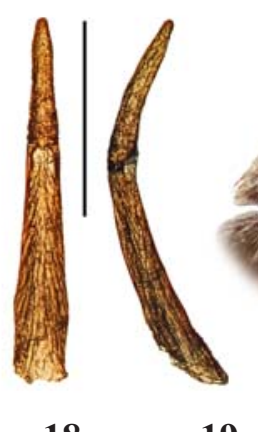

18

19
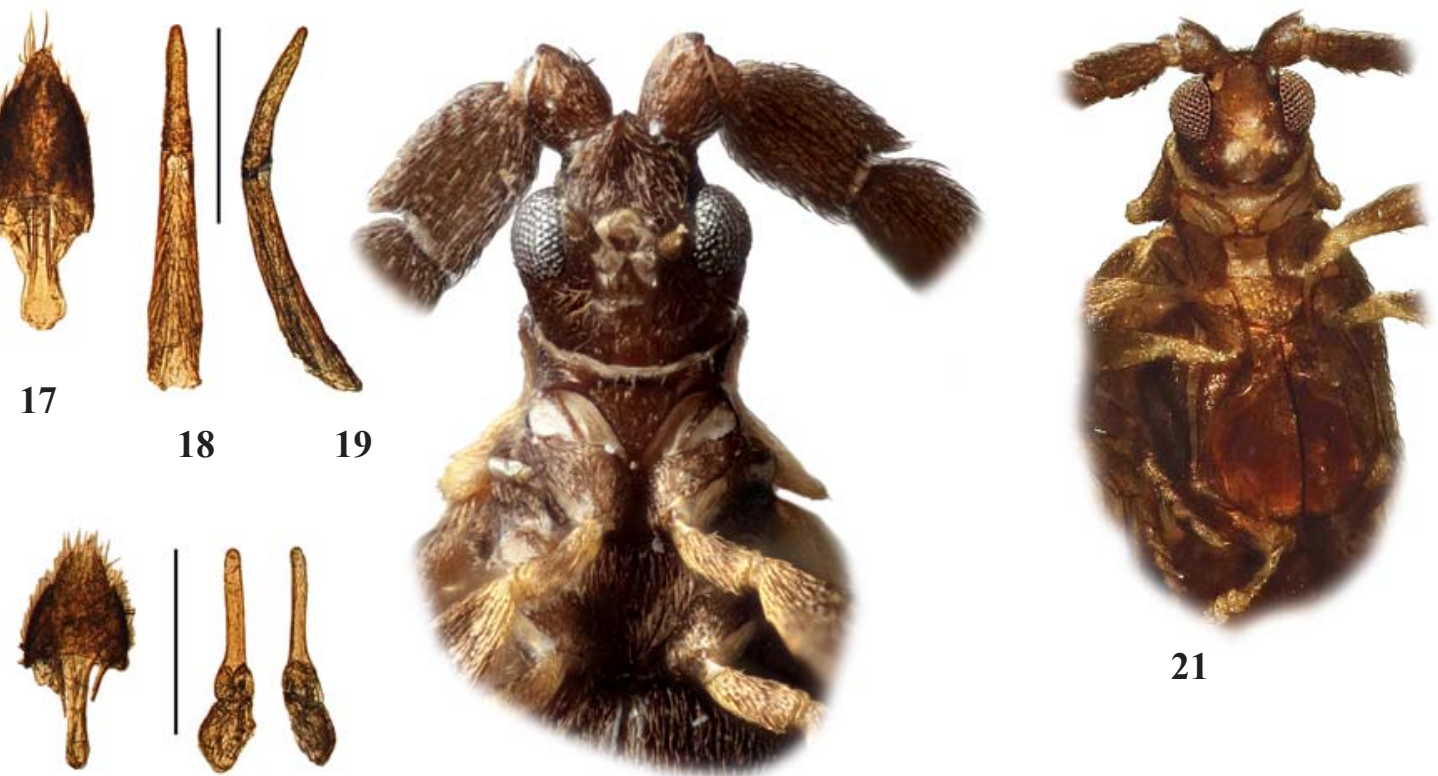

21

23

24

25

15

Figs 14-25. General view and details of Aplopteron gen.n. and Ceratolycus gen.n., male holotypes: 14-19 - A. yasuniense sp.n.; 2025 - A. victoriae sp.n.; 14, 20 - general view; 15,21 - anterior part of body; 16, 22 - labium; 17, 23 - ultimate abdominal segments; 18-19, 24-25 - aedeagus; 14, 17-18, 20, 23-24 - dorsally; 15-16, 21-22 - ventrally; 19, 25 - laterally. Scales: $0.5 \mathrm{~mm}$.

Рис. 14-25. Общий вид и детали строения Aplopteron gen.n. и Ceratolycus gen.n., голотипы, самцы: 14-19 - A. yasuniense sp.n.; 20-25 - A. victoriae sp.n.; 14, 20 - общий вид; 15, 21 - передняя часть тела; 16, 22 - нижняя губа; 17, 23 - вершинные сегменты брюшка; 18-19, 24-25 - эдеагус; 14, 17-18, 20, 23-24 - сверху; 15-16, 21-22 - снизу; 19, 25 - сбоку. Масштабные линейки: 0,5 мм. 


\section{Ceratolycus Kazantsev, gen.n.}

Type species: Ceratolycus victoriae sp.n.

DESCRIPTION. Male. Alate, slender, elongate (Fig. 20). Head subquadrate, slightly narrowed behind eyes. Fastigium acute, ca. 45 degrees. Eyes relatively small, flattened. Labrum small, lightly sclerotized, lying inside epistoma. Mandibles vestigial. Maxillary palps slender, 4-segmented, with ultimate palpomere pointed distally. Labium consisting of non-paired prementum and rudiments of a pair of one-segment palps (Fig. 22). Gula absent. Antennal prominence relatively inconspicuous, antennal sockets separated by minute lamina. Antenna 11segmented, relatively long, from antennomere 3 flattened and serrate; antennomere 2 short, transverse, considerably shorter and smaller than antennomere 3 ; pubescence on antennomeres 3-11 short and decumbent (Figs 20-21).

Pronotum small, over 9 times shorter than elytra, with somewhat obscured narrow median areole attaining to anterior and posterior margins; posterior angles produced laterally, anterior angles conspicuous (Fig. 20). Prosternum short, Yshaped (Fig. 21). Thoracic spiracles elongate, small, protruding beyond coxae. Mesoventrite transverse, not divided by median suture. Mesonotum with scutellum attaining to anterior margin, scutal halves not divided. Elytra long, almost parallelsided, dehiscent in distal two thirds, completely covering wings, with two developed primary costae (2 and 4); interstices finely irregularly areolate; short elytral pubescence scarce and uniform (Fig. 20). Metanotum subquadrate, scuto-scutellar ridge straight, noticeably longer than allocrista; prescutum with median suture; intrascutal suture small, emerging at distal third of scutum; scutellum with median suture; postnotal plate short, with median suture. Metaventrite elongate, with slightly rounded posterior angles; discrimen complete, attaining to mesosternum. Metathoracic wing with fringe of short hairs; anal cell closed; wedge cell absent, $\mathrm{Cu}$ veins present.

Protrochantins narrow, similar to mesotrochantins. Proand mesocoxae elongate; metacoxae separated. Legs slender; trochanters elongate, but relatively short, cylindrical, connected to femora distally; femurs and tibiae flattened, straight and somewhat widened distally, tibial spurs absent; tarsomeres 1-4 narrow, without plantar pads; all claws simple.

Abdominal spiracles miniature, unipartite, located on membrane between tergite and sternite. Paraproct not divided by median suture; sternite 9 with relatively long, rounded proximally spiculum gastrale (Fig. 23).

Aedeagus symmetric, with short roundish parameres and elongate narrow median lobe; parameral apices rounded; phallobase divided by median suture (Figs 24-25).

Female. Unknown, probably paedomorphic and larviform.

BIOLOGY. All specimens of Ceratolycus gen.n. were collected in the Amazon selva by flight intercept traps.

ETYMOLOGY. The name of the genus is derived from the genus name "Ceratoprion", alluding to its similarity to this genus, and the genus name "Lycus", the type genus of the family. Gender masculine.

DIAGNOSIS. Ceratolycus gen.n. is readily differentiated from the habitually similar Aplopteron gen.n. by the less conspicuous antennal prominence, $\mathrm{Y}$-shaped prosternum, considerably more elongate pro- and mesocoxae, only slightly widened posteriorly spiculum gastrale and developed parameres and relatively short and closed proximally phallobase of the aedeagus (Figs 20-25). It is easily separated from the also similar Ceratoprion by the large third antennomere.

REMARKS. Only one species is known in this genus.

DISTRIBUTION. Ecuador and Peru.

\section{Ceratolycus victoriae Kazantsev, sp.n.}

Figs 20-25.

MATERIAL: Holotype, $\sigma^{7}$, Ecuador: Orellana, Tiputini Biol. Stn., 0`39.5'S, 76²6’W, FIT, 28.VII-3.VIII.2008, A. Tishechkin leg. (ICM); paratypes: $\sigma^{7}$, Ecuador: Napo, Yasuni Res. Stn. mid. Rio Tiputini, 040.5'S, 76²4'W, FIT, 20-29.VI.1999, C. Carlton \& V. Moseley leg.; $\sigma^{7}$, Ecuador: Napo, Yasuni Res. Stn. mid. Rio Tiputini, $0^{\circ} 40.5$ 'S, $76^{\circ} 24^{\prime} \mathrm{W}$, FIT, 23-30.VI.1999, A. Tishechkin \& C. Carlton leg.; $2 \bigcirc^{7} \sigma^{7}$, Ecuador: Napo, Yasuni Res. Stn. mid. Rio Tiputini, 040.5'S, 76²4'W, FIT, 28.VI-5.VII.1999, C. Carlton \& A. Tishechkin leg.; $\Im^{T}$, Ecuador: Napo, Yasuni, Yasuni Res. Stn., $0^{\circ} 40.5^{\prime} \mathrm{S}, 7^{\circ} 24^{\prime} \mathrm{W}$, FIT, 25.VII-3.VIII.1999, A. Tishechkin leg.; 2 $\sigma^{\top} \sigma^{\top}$, Ecuador: Orellana, Yasuni Res. Stn., FIT, 11-26.VII.2008, A. Tishechkin leg.; $\sigma^{\top}$, Ecuador: Orellana, Yasuni N.P., Via Maxus at Qued, Pirana Bridge, $0^{\circ} 39.5^{\prime} \mathrm{S}, 7^{\circ} 26^{\prime} \mathrm{W}$, FIT, 14-24.VII.2008, A. Tishechkin leg. (ICM and LSAM); $\sigma^{7}$, Peru: Loreto, Rio Amazon, 58-68 km SSW Iquitos (to Nauta), $4^{\circ} 15^{\prime} \mathrm{S}, 7^{\circ} 28^{\prime} \mathrm{W}, 120-140 \mathrm{~m}$, primary rainforest, FIT, 20-24.IX.2015, A. Petrov leg. (ICM).

DESCRIPTION. Male. Dark brown; antennomere 2, trochanters and bases of femoris light brown; antennomere 11 yellow.

Vertex shining, finely punctate, prominently impressed behind antennal prominence. Eyes small, interocular distance ca. 1.4 times greater than eye diameter. Maxillary palps slender, ultimate palpomere elongate, narrow and glabrous distally. Antennal sockets separated by narrow lamina. Antennae strongly flattened, serrate, attaining to elytral two thirds; antennomere 3 ca. 8 times longer than antennomere 2 and ca. 1.2 times shorter than antennomere 4; antennomeres 3-11 with short decumbent pubescence (Fig. 20).

Pronotum strongly transverse, ca. 1.9 times as wide as long, trapezoidal, with slightly concave sides, bisinuate basally and almost straight anteriorly, with prominent acute posterior and conspicuous right anterior angles. Scutellum subquadrate, narrowing distally and emarginate at apex (Fig. 20).

Elytra narrow, long, ca. 3.7 times longer than wide at humeri, with two slender, equally developed primary costae; all interstices finely and densely irregularly areolate; pubescence scarce, short and decumbent (Fig. 20). Femoris and tibiae straight, relatively broad; all tarsomeres narrow, lacking plantar pad.

Aedeagus with narrow, straight, cylinder-like and rounded apically median lobe; paramers short, ca. 0.2 length of median lobe; phallobase sub-oval, ca. 0.5 length of median lobe (Figs 24-25).

Female. Unknown.

Length: 2.5-3.4 mm. Width (humerally): 0.5-0.7 mm.

ETYMOLOGY. The new species is named after one of the collectors of the type series, Dr. V. Bayless (Baton Rouge, Louisiana).

DIAGNOSIS. Ceratolycus victoriae sp.n. can be separated from other leptolycines by the generic characters, i.e., by the large antennomere 3 , irregularly areolate elytra and aedeagus with developed short roundish parameres and oval phallobase divided by median suture (Figs 20-25).

DISTRIBUTION. Amazon basin, Ecuador and Peru.

\section{Petrovia Kazantsev, gen.n.}

Type species: Petrovia clavicula sp.n.

DESCRIPTION. Male. Alate, slender, elongate (Fig. 26). Head transverse, not narrowed behind eyes. Fastigium acute, ca. 15 degrees. Eyes relatively small, spherical. Labrum small, lightly sclerotized, lying inside epistoma. Mandibles reduced. Maxillary palps slender, 4-segmented, with ultimate palpomere narrow, pointed distally. Labium consisting of undivided prementum and two-segment palps, ultimate palpomere narrowed 
and pointed distally (Fig. 28). Antennal prominence relatively inconspicuous; antennal sockets separated by minute lamina. Antenna 11-segmented, moderately long; antennomeres 4-10 narrow, parallel-sided, slightly compressed; antennomere 2 considerably shorter than antennomere 3 ; pubescence on antennomeres 3-11 relatively short and decumbent (Figs 26-27).

Pronotum transverse, narrow, over 10 times shorter than elytra, trapezoidal, with obscure median areole prominent acute posterior angles (Fig. 26). Prosternum short, Y-shaped. Thoracic spiracles elongate, small, slightly protruding beyond coxae. Mesoventrite elongate, triangular, not divided by median suture. Mesonotum anteriorly triangularly incised, scutellum almost attaining to anterior margin, scutal halves divided; scutellum elongate, with deeply incised postnotal projection. Elytra long, almost parallel-sided, with four almost equally developed primary costae; interstices with single row of large elongate cells; elytral pubescence scarce and decumbent (Fig. 26). Metanotum elongate; scuto-scutellar ridge slightly convex, considerably longer than allocrista; prescutum with median keel at posterior fourth; intrascutal suture small, emerging at ca. middle of scutum; scutellum without median suture; postnotal plate transverse, short, without median suture. Metaventrite subquadrate, with acute posterior angles; discrimen complete, attaining to mesosternum. Metathoracic wing with anal cell closed; wedge cell present, $\mathrm{Cu}$ veins proximally obsolete.

Protrochantins similar to mesotrochantins. Pro- and mesocoxae elongate; metacoxae approximate. Legs relatively short; trochanters short, connected to femora distally; pro- and mesotrochanters cylindrical, metatrochanters slightly widened distally; femurs and tibiae conspicuously flattened, straight, tibiae noticeably longer than femurs, tibial spurs hardly visible, not quite separable from surrounding vestiture; tarsomeres narrow, without plantar pads; all claws simple.

Abdominal spiracles dorsal, located on membrane, at the edge of sternites. Paraproct subdivided medially; sternite 9 with slightly asymmetric, narrowing proximally spiculum gastrale (Fig. 29).

Aedeagus symmetric, with elongate, straight and rounded at apex median lobe; parameres free, short and roundish; phallobase oval, narrowing proximally (Figs 30-31).

Female. Unknown, probably paedomorphic and larviform.

ETYMOLOGY. The genus is named after Dr. Aleksander Petrov (Moscow), whose 1999 and 2005-2015 expeditions to Peru have yielded many interesting leptolycine specimens. Gender feminine.

DIAGNOSIS. Petrovia gen.n. is easily differentiated from the somewhat similar Andepteron gen.n. by the ventrally straight at posterior margin head (Fig. 27), narrow, pointed at apex ultimate labial palpomere (Fig. 28), obscure median pronotal areole, divided scutal halves of the mesonotum, hairy elytra (Fig. 26) and relatively short, semi-triangular trochanters, as well as by the proximally narrowed and asymmetric spiculum gastrale (Fig. 29) and slenderer aedeagus, with elongate median lobe and short parameres (Figs 30-31).

REMARKS. Only one species is known in this genus.

DISTRIBUTION. Peru.

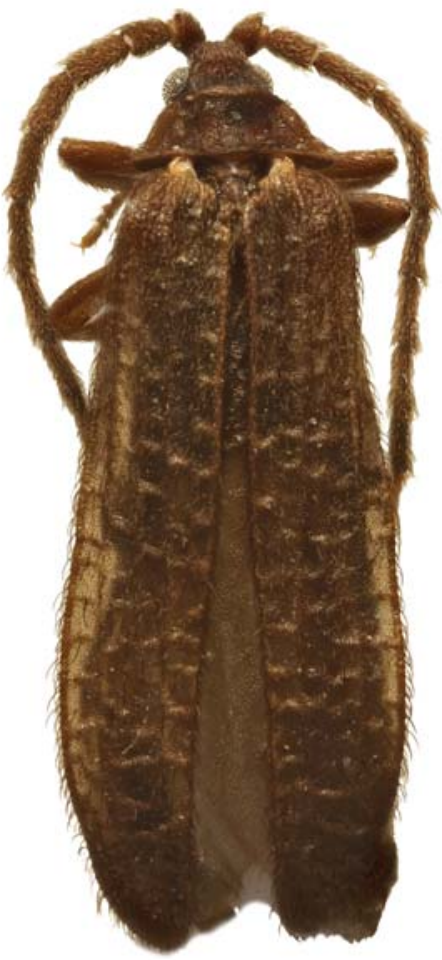

26

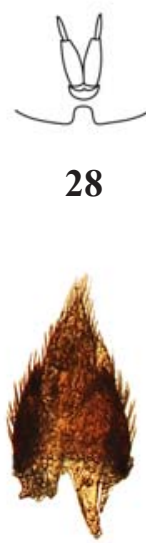

29

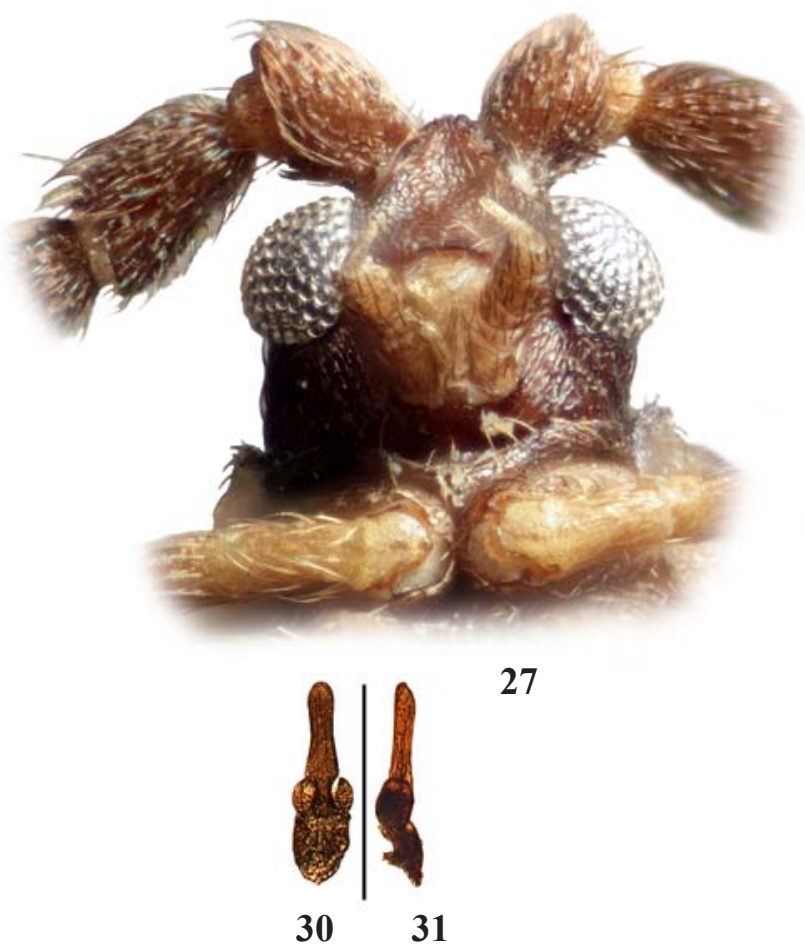

Figs 26-31. General view and details of Petrovia yasuniense gen.n., sp.n., male holotype: 26 — general view; 27 — anterior part of body; 28 labium; 29 - ultimate abdominal segments; 30-31 - aedeagus; 26, 29-30 - dorsally; 27-28 — ventrally; 31 - laterally. Scale: 0.5 mm.

Рис. 26-31. Общий вид и детали строения Petrovia yasuniense gen.n., sp.n., голотип, самец: 26 - общий вид; 27 - передняя часть тела; 28 - нижняя губа; 29 - вершинные сегменты брюшка; 30-31 - эдеагус; 26, 29-30- сверху; 27-28- снизу; 31 - сбоку. Масштабная линейка: 0,5 мм. 


\section{Petrovia clavicula Kazantsev, sp.n.} Figs 26-31.

MATERIAL: Holotype, ơ, Peru: Huanuco, 40 km NNW, Tingo Maria, Sta Marta, 1200-1600 m, 15-16.V.2008, A. Petrov leg. (ICM).

DESCRIPTION. Male. Dark brown; antennomere 2, elytral basal struts, trochanters and bases of femoris light brown; antennomere 11 yellow.

Vertex densely and roughly punctate, with shallow transverse impression and narrow median keel behind antennal prominence. Eyes small, interocular distance ca. 1.5 times greater than eye diameter. Maxillary palps slender, ultimate palpomeres elongate, needle-shaped, pointed and glabrous distally. Antennae attaining to elytral two thirds; antennomere 3 ca. 7 times longer than antennomere 2 and ca. 1.4 times shorter than antennomere 4 (Fig. 26).

Pronotum transverse, ca. 2.5 times as wide as long, trapezoidal, with straight sides, slightly bisinuate basally and straight anteriorly, with strongly produced latero-posteriorly posterior and blunt anterior angles. Scutellum elongate, parallel-sided, emarginate at apex (Fig. 26).

Elytra narrow, long, ca. 3.4 times longer than wide at humeri, slightly widening distally, with primary costa 1 present in proximal two thirds; all cells in interstices ca. 1.5 times longer than wide (Fig. 26).

Aedeagus relatively robust; parameres attaining to ca. 0.3 of median lobe; phallobase ca. 0.5 length of median lobe (Figs 30-31).

Female. Unknown.

Length: $3.7 \mathrm{~mm}$. Width (humerally): $1.0 \mathrm{~mm}$.

ETYMOLOGY. The name of the new species is derived from the Latin for "collarbone", alluding the conspicuousness of the said structure.

DIAGNOSIS. Petrovia clavicula sp.n. can be easily separated from other leptolycines by the generic characters (Figs 26-31).

DISTRIBUTION. Known only from Peru.

$$
\text { Cephalolycus Pic, } 1926
$$

Cephalolycus Pic, 1926: 30.

type species (by monotypy) Cephalolycus major Pic, 1926.

REMARKS. The holotype of the type species and the only member of the genus, Cephalolycus major Pic, 1926, which lacks legs and has damaged aedeagus, has been studied [Ferreira, Ivie, 2016]. Examination of further material from the genus, with intact legs and aedeagi, allows to assert that Cephalolycus Pic, 1926 belongs in Leptolycini. Therefore, Cephalolycus is transferred from Calopterini (Lycinae) to Leptolycini (Leptolycinae).

Until now a monotypic genus. Two additional species were discovered in the Ecuador material.

DISTRIBUTION. Colombia and Ecuador.

\section{Cephalolycus cajanumensis Kazantsev, sp.n.} Figs 32-35.

MATERIAL: Holotype, $\sigma^{7}$, Ecuador: Zamora Chinchipe, Podocarpus N.P., Cajanuma Stn., 2850-3250 m, cloud forest, 34.VII.2016, S. \& S. Kazantsev leg. (ICM).

DESCRIPTION. Male. Black; apex of antennomere 11 and broad elytral postdiscal band orange testaceous.

Vertex shining, finely punctate, with roundish impression and short narrow median keel behind antennal prominence. Eyes relatively small, interocular distance ca. 1.6 times greater than eye diameter. Maxillary palps slender, tapering, narrow and pointed at apex. Antennal sockets separated by minute lamina. Antennae relatively short, attaining to elytral half, from antennomere 4 flabellate; antennomeres 2 and 3 subequal in length, antennomere 4 ca. 2.8 times longer than antennomeres 2 and 3 combined and subequal in length to antennomere 5; flabellae of antennomeres 4 and 5 ca. 1.5 and 1.8 times longer than relevant stems; pubescence short and decumbent (Fig. 32).

Pronotum short, ca. 12 times shorter than elytra, transverse, about 1.8 times as wide as long, trapezoidal, constricted near anterior margin, bisinuate basally and slightly rounded anteriorly, with strongly produced acute posterior and blunt anterior angles (Fig. 32). Mesothoracic spiracle protruding beyond coxa. Scutellum subquadrate, nearly parallelsided, convex at apex (Fig. 32).

Elytra long, ca. 5.2 times longer than wide at humeri, conspicuously widening distally, dehiscent in distal two thirds, with complete, equally developed, but slender primary costae 1, 2 and 4; interstices with large elongate to transverse cells; elytral pubescence short and uniform (Fig. 32).

Paraproct not divided by median suture (Fig. 33). Aedeagus with relatively long and narrow median lobe; parameres attaining to ca. 0.2 of median lobe; phallobase ca. 0.2 length of median lobe (Figs 34-35).

Female. Unknown.

Length: $9.0 \mathrm{~mm}$. Width (humerally): $1.7 \mathrm{~mm}$.

ETYMOLOGY. The name of the new species is derived from the locality, where the unique type specimen was taken.

DIAGNOSIS. Cephalolycus cajanumensis sp.n. can be easily separated from $C$. major and $C$. pichinchensis sp.n. by the coloration, flabellate antennae and more slender and elongate median lobe of the aedeagus (Figs 32, 34-35).

DISTRIBUTION. Known only from the Andes in Ecuador.

\section{Cephalolycus pichinchensis Kazantsev, sp.n.} Figs 36-39.

MATERIAL: Holotype, $\sigma^{\top}$, Ecuador: Pichincha, Rd. Aloag - S. Domingo, 1900 m, cloud forest, 10.VII.2016, S. \& S. Kazantsev leg. (ICM).

DESCRIPTION. Male. Black; antennomeres 2-3 light brown; elytral apices orange testaceous.

Vertex shining, finely punctate, with roundish impression and short narrow median keel behind antennal prominence. Eyes small, interocular distance ca. 1.9 times greater than eye diameter. Labial palps minute, ultimate palpomeres spine-like. Antennal sockets separated by minute lamina. Antennae flattened, from antennomere 4 serrate; antennomeres 2 and 3 subequal in length, antennomere 4 ca. 2.9 times longer than antennomeres 2 and 3 combined and ca. 1.1 times shorter than antennomere 5; pubescence short and decumbent (Fig. 36).

Pronotum short, ca. 13.5 times shorter than elytra, transverse, about 2.6 times as wide as long, trapezoidal, constricted near anterior margin, bisinuate basally and rounded anteriorly, with acute, strongly produced laterally posterior and blunt rounded anterior angles (Fig. 36). Mesothoracic spiracle relatively large, protruding beyond coxa. Scutellum transverse, triangular, truncate at apex (Fig. 36).

Elytra long, ca. 4.3 times longer than wide at humeri, conspicuously widening distally, dehiscent in distal two thirds, with complete, equally developed, prominent primary costae 1, 2 and 4; interstices with obscure transverse cells; elytral pubescence short and uniform (Fig. 36).

Paraproct divided by median suture (Fig. 37). Aedeagus with relatively short and somewhat broader median lobe; parameres attaining to ca. 0.25 of median lobe; phallobase ca. 0.35 length of median lobe (Figs 38-39). 
Female. Unknown.

Length: $7.5 \mathrm{~mm}$. Width (humerally): $1.5 \mathrm{~mm}$.

ETYMOLOGY. The name of the new species is derived from the province, where the unique type specimen was taken.
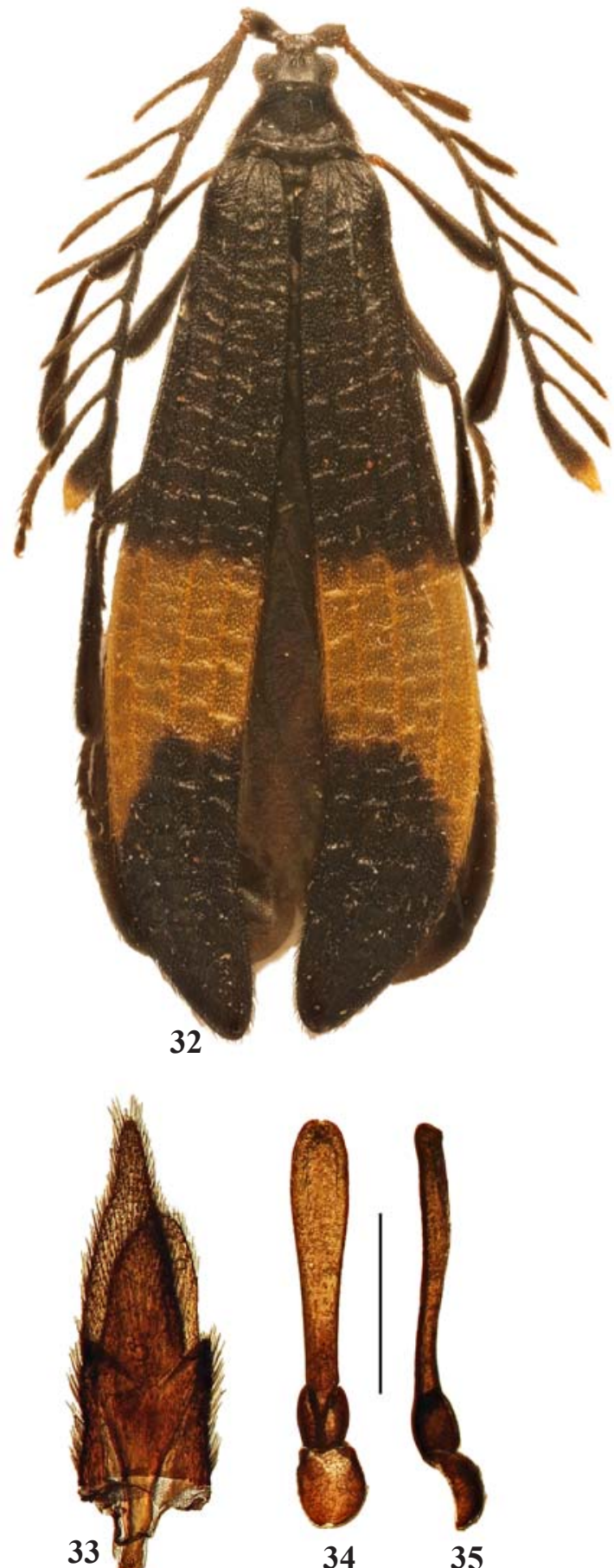

DIAGNOSIS. Cephalolycus pichinchensis sp.n. is readily distinguishable from $C$. cajanumensis sp.n. by the coloration, non-flabellate antennae and somewhat more robust median lobe of the aedeagus (Figs 36, 38-39). It may also be easily separated from $C$. major by the coloration.
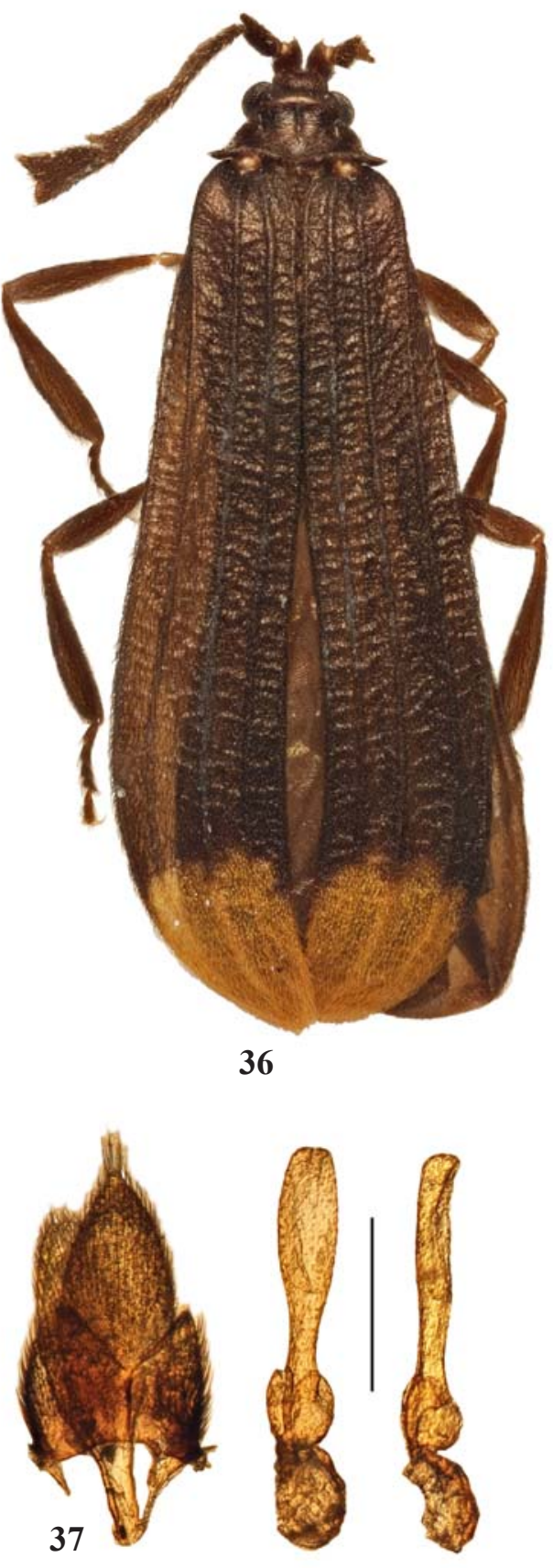

38

Figs 32-39. General view and details of Cephalolycus, male holotypes: 32-35 - C. cajanumensis sp.n.; 36-39-C. pichinchensis sp.n.; 32, 36 - general view; 33, 37 - ultimate abdominal segments; 34-35, 38-39 - aedeagus; 32-24, 36-38 - dorsally; 35, 39 — laterally. Scales: $0.5 \mathrm{~mm}$

Рис. 32-39. Общий вид и детали строения Cephalolycus, голотипы, самцы: 32-35 - C. cajanumensis sp.n.; 36-39 - C. pichinchensis sp.n.; 32, 36 - общий вид; 33, 37 - вершинные сегменты брюшка; 34-35, 38-39 - эдеагус; 32-24, 36-38 - сверху; 35,39 - сбоку. Масштабные линейки: 0,5 мм. 
REMARKS. Maxillary palps are absent and only six antennomeres are present in the unique holotype of $C$. pichinchensis sp.n.; the structure and coloration of antennomeres 7-11 are, therefore, unknown.

DISTRIBUTION. Known only from the Andes in Ecuador.

\section{Ceratoprion Gorham, 1884}

Ceratoprion Gorham, 1884: 348. 1884.

type species (by monotypy) Ceratoprion serricorne Gorham,

REMARKS. Three species have been known in this genus so far, two from Central America and one from Venezuela [Kleine, 1933; Kazantsev, Zaitsev, 2009; Kazantsev, 2013]. Additional three species from Ecuador and Peru are described below.

DISTRIBUTION. Costa Rica, Panama, Venezuela, Ecuador and Peru.

\section{A key to SPeCies of CERATOPRION Gorham, 1884 of Ecuador and Peru}

1. Eyes large, eye diameter considerably longer than interocular distance (Fig. 44). Median lobe the aedeagus distally ovally widened (Figs 46-47) C. diosense sp.n.

- Eyes small, eye diameter noticeably shorter than interocular distance (Figs 44, 48) .....

2. Only ultimate antennomere yellowish (Fig 40). Paramere of the aedeagus broad, median lobe distally transversely widened (Figs 42-43)....

C. alexi sp.n.

- Two ultimate antennomeres yellowish (Fig. 48). Median lobe and parameres of the aedeagus narrow and pointed apically (Figs 51-52) C. loretense sp.n.

\section{Ceratoprion alexi Kazantsev, sp.n.} Figs 40-43.

MATERIAL: Holotype, $\sigma^{7}$, Ecuador: Orellana, Yasuni Res Stn., FIT, 11-26.VII.2008, A. Tishechkin leg. (ICM); paratypes: 7 $\mathrm{O}^{2} \mathrm{O}^{2}$, same label; $5 \mathrm{O}^{2} \mathrm{O}^{2}$, Ecuador: Napo, Yasuni Res. Stn. mid. Rio Tiputini, $0^{\circ} 40.5^{\prime} \mathrm{S}, 7^{\circ} 24^{\prime} \mathrm{W}$, FIT, 28.VI-5.VII.1999, C. Carlton \& A. Tishechkin leg.; $\sigma^{7}$, Ecuador: Napo, Yasuni Res. Stn. mid. Rio Tiputini, $0^{\circ} 40.5^{\prime} \mathrm{S}, 76^{\circ} 24^{\prime} \mathrm{W}$, FIT, 20-29.VI.1999, C. Carlton \& V. Moseley leg.; $\bigcirc^{7}$, Ecuador: Napo, Yasuni Res. Stn. mid. Rio Tiputini, $0^{\circ} 40.5^{\prime}$ 'S, 76²4'W, FIT, 4-17.VII.1999, C. Carlton leg. (ICM and LSAM); $\sigma^{7}$, Peru: Loreto, Rio Amazon, 58-68 km SSW Iquitos (to Nauta), $4^{\circ} 15^{\prime} \mathrm{S}, 73^{\circ} 28^{\prime} \mathrm{W}, 120-140 \mathrm{~m}$, primary rainforest, FIT, 20-24.IX.2015, A. Petrov leg. (ICM).

DESCRIPTION. Male. Dark brown to black; coxae and trochanters light brown; ultimate antennomere yellowish.

Vertex shining, finely and densely punctate, with roundish impression behind antennal prominence. Eyes small, flattened, interocular distance ca. 1.1 times greater than eye diameter. Maxillary palps minute, tapering. Antennal sockets separated by minute lamina. Antennae flattened, serrate, attaining to elytral two thirds; antennomere 4 ca. 2 times longer than antennomeres 2 and 3 combined and subequal in length to antennomere 5; antennomeres 4-11 with short decumbent pubescence (Fig. 40).

Pronotum transverse, ca. 2.4 times as wide as long, trapezoidal, with concave sides, bisinuate basally and almost straight anteriorly, with prominent laterally produced acute posterior and pronounced anterior angles; median keel narrow. Scutellum transverse, almost parallel-sided, conspicuously emarginate at apex (Fig. 40).

Elytra narrow, long, ca. 4 times longer than wide at humeri, almost parallel-sided, dehiscent at distal two thirds, with slender, equally developed primary costae 2 and 4 ; interstices roughly rugulose; scarce pubescence relatively long and semi-erect (Fig. 40). Femoris and tibiae straight, narrow; tarsomeres narrow, without plantar pad (Fig. 40).

Paraproct deeply incised; ultimate ventrite (sternite 9) with narrowing proximally spiculum gastrale (Fig. 41). Aedeagus with broadly widened distally median lobe; parameres broad, conspicuously diverging distally; phallobase medially divided by suture, attaining to ca. 0.5 length of median lobe (Figs 42-43).

Female. Unknown.

Length: $3.0-3.7 \mathrm{~mm}$. Width (humerally): $0.6-0.8 \mathrm{~mm}$.

ETYMOLOGY. The species is named after Dr. Aleksey Tishechkin (Santa Barbara, California, USA), who collected the bulk of its type series.

DIAGNOSIS. Ceratoprion alexi sp.n. appears to be close to $C$. diosense sp.n., separable by the smaller eyes and more dilated distally median lobe of the aedeagus (Figs 40, 42-43).

DISTRIBUTION. Amazon basin, Ecuador and Peru.

\section{Ceratoprion diosense Kazantsev, sp.n.}

Figs 44-47.

MATERIAL: Holotype, $0^{7}$, Peru: Madre de Dios, P.N. Tambopata, ca. $150 \mathrm{~m}, 25 . X .2012$ (ICM); paratypes, $2 \mathrm{O}^{7} \sigma^{7}$, same label (ICM).

DESCRIPTION. Male. Dark brown to black; anterior and posterior margins of pronotum light brown; trochanters and tarsi testaceous; ultimate antennomere yellowish.

Vertex flat and densely punctate behind antennal prominence, between eyes with roundish impression. Eyes large, spherical, interocular distance ca. 2.2 times shorter than eye diameter; in lateral view conspicuously incised in lower half. Maxillary palps minute, tapering distally. Antennal sockets separated by minute lamina. Antennae flattened, serrate, attaining to elytral three fifths; antennomere 4 ca. 3.3 times longer than antennomeres 2 and 3 combined and ca. 1.2 times shorter than antennomere 5; antennomeres 4-11 with short decumbent pubescence (Fig. 44).

Pronotum transverse, ca. 2.4 times as wide as long, trapezoidal, with concave sides, bisinuate basally and rounded anteriorly, with prominent latero-posteriorly produced acute posterior and pronounced anterior angles; median keel noticeably divided in anterior two thirds to for a cell. Scutellum transverse, almost parallel-sided, deeply emarginate at apex (Fig. 44).

Elytra narrow, long, ca. 4.1 times longer than wide at humeri, almost parallel-sided, dehiscent at distal two thirds, with slender, equally developed primary costae 2 and 4; interstices rather delicately rugulose; scarce pubescence relatively long and semi-erect (Fig. 44). Femoris and tibiae straight, narrow; tarsomeres narrow, without plantar pad (Fig. 44).

Paraproct triangularly incised; ultimate ventrite (sternite 9) with narrowing proximally spiculum gastrale (Fig. 45). Aedeagus with transversely widened distally median lobe; parameres oval; phallobase medially divided by suture, attaining to ca. 0.6 length of median lobe (Figs 46-47).

Female. Unknown.

Length: $3.8-4.2 \mathrm{~mm}$. Width (humerally): $0.6-0.9 \mathrm{~mm}$.

ETYMOLOGY. The new species is named after the type locality.

DIAGNOSIS. Ceratoprion diosense sp.n. appears to be similar to C. serricorne Gorham, 1884 from Panama, separable by the mostly dark brown pronotum; apart from the aedeagus, it may also be individuated from the congeners by the large, bulging and incised in lateral view eyes (Figs 44, 46-47).

DISTRIBUTION. Known only from Madre de Dios, in southeastern Peru. 
Ceratoprion loretense Kazantsev, sp.n.

Figs 48-52.

MATERIAL: Holotype, $\sigma^{7}$, Peru: Loreto, Rio Amazon, 58-68 $\mathrm{km}$ SSW Iquitos (to Nauta), $4^{\circ} 15^{\prime} \mathrm{S}, 73^{\circ} 28^{\prime} \mathrm{W}, 120-140 \mathrm{~m}$, primary rainforest, FIT, 20-24.IX.2015, A.Petrov leg. (ICM); paratypes: $0^{7}$, same label; $O^{7}$, Ecuador: Orellana, Yasuni Res. Stn., FIT, 1126.VII.2008, A. Tishechkin leg. (ICM).

DESCRIPTION. Male. Dark brown to black; trochanters and bases of femoris testaceous; penultimate and ultimate antennomeres yellowish.

Vertex densely and finely punctate, with conspicuous roundish impression behind antennal prominence. Eyes small, flattened, interocular distance ca. 1.3 times greater than eye diameter. Maxillary palps minute and tapering distally. Antennal sockets separated by minute lamina. Antennae flattened, strongly serrate, attaining to elytral two thirds; antennomere 4 ca. 3.9 times longer than antennomeres 2 and 3 combined and subequal in length to antennomere 5; antennomeres 4-11 with short decumbent pubescence (Fig. 48).

Pronotum transverse, ca. 2.4 times as wide as long, trapezoidal, with concave sides, bisinuate basally and slightly rounded anteriorly, with prominent latero-posteriorly produced acute posterior and pronounced blunt anterior angles; median keel narrowly divided in posterior half. Scutellum transverse, almost parallel-sided, emarginate at apex (Fig. 48).

Elytra narrow, long, ca. 3.7 times longer than wide at humeri, almost parallel-sided, dehiscent at distal two thirds, with slender primary costae 2 and 4 and traces of costae 1 and 3 between them; interstices obscurely areolate; pubescence relatively dense and decumbent (Fig. 48). Femoris and tibiae straight, narrow; tarsomeres narrow, without plantar pad (Fig. 48).

Paraproct triangularly incised (Fig. 49); ultimate ventrite (sternite 9) with parallel-sided spiculum gastrale (Fig. 50).

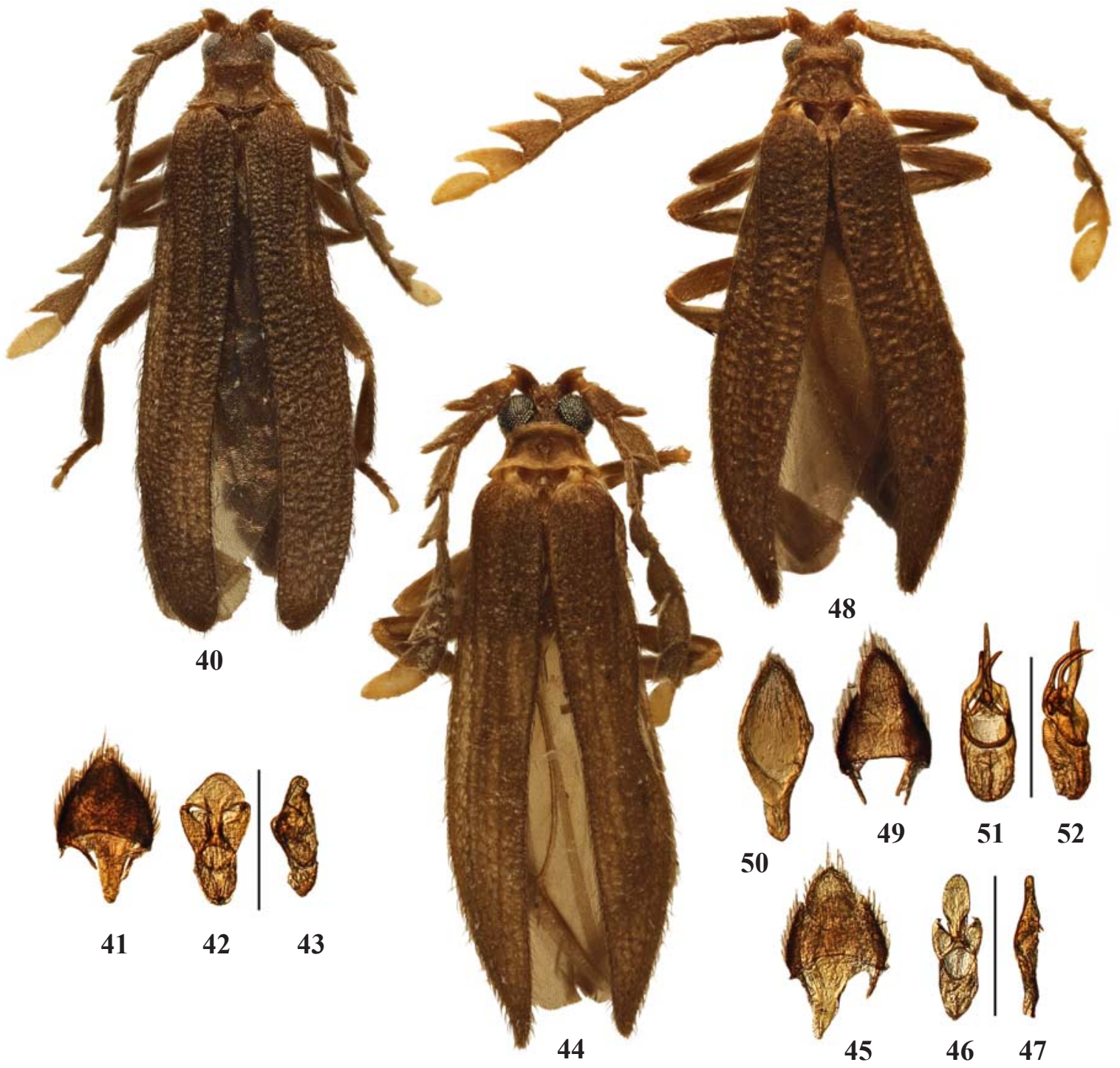

Figs 40-52. General view and details of Ceratoprion, male holotypes: 40-43-C. alexi sp.n.; 44-47-C. diosense sp.n.; 48-52 C. loretense sp.n.; 40, 44, 48 - general view; 41, 45, 49-50 - ultimate abdominal segments; 42-43, 46-47, 51-52 - aedeagus; 40-41, 44-45, 48, 50 - dorsally; 42, 46, 49, 51 - ventrally; 43, 47, 52 - laterally. Scales: $0.5 \mathrm{~mm}$.

Рис. 40-52. Общий вид и детали строения Ceratoprion, голотипы, самцы: 40-43-C. alexi sp.n.; 44-47 - C. diosense sp.n.; 4852 - C. loretense sp.n.; 40, 44, 48 - общий вид; 41, 45, 49-50 - вершинные сегменты брюшка; 42-43, 46-47, 51-52 - эдеагус; 4041, 44-45, 48, 50 - сверху; 42, 46, 49, 51 - снизу; 43, 47, 52 - сбоку. Масштабные линейки: 0,5 мм. 
Aedeagus with narrow spine-like parameres and narrow, pointed apically median lobe; phallobase medially divided by suture, attaining to ca. 0.6 length of median lobe (Figs 51-52).

Female. Unknown.

Length: $3.9-4.1 \mathrm{~mm}$. Width (humerally): $0.7-0.8 \mathrm{~mm}$.

ETYMOLOGY. The new species is named after the province where two of the three type specimens were collected.

DIAGNOSIS. Ceratoprion loretense sp.n. is quite different from the congeners in the elytral structure, shape of the paraproct and the structure of the aedeagus, with the narrow spine-like parameres and narrow, pointed apically median lobe (Figs 48-52). It may additionally be distinguished from C. alexi sp.n. and $C$. diosense sp.n. by the two yellow ultimate antennomeres (Fig. 48)

DISTRIBUTION. Amazon basin, Ecuador and Peru.

\section{Flabellocaenia Pic, 1929}

Flabellocaenia Pic, 1929: 76. 1929.

type species (by monotypy) Flabellocaenia bourgeoisi Pic,

REMARKS. So far a monotypic genus, with its type species described from Brazil [Kleine, 1933]. Additional four species from Ecuador and Peru are described below.

DISTRIBUTION. Brazil, Ecuador and Peru.

A key to species of F Labellocaenia Pic, 1929 of Ecuador AND PERU

1. Flabellum of antennomere 4 only ca. 3 times longer than antennal stem (Fig. 54) ................... F. ocopensis sp.n.

- Flabellum of antennomere $4 \mathrm{ca} .10-20$ times longer than antennal stem (Figs 53, 55-56) ................................... 2

2. Elytra dark brown, with testaceous bases (Fig. 53). Median lobe and parameres of the aedeagus elongate, oval (Figs 58-59) F. iquitosensis sp.n.

- Elytra testaceous, with dark brown postdiscal band and (sometimes) dark brown sutural area (Figs 55-56). Median lobe and parameres of the aedeagus either more narrow or more roundish (Figs 65-66, 68-69)

3. Elytra with dark brown postdiscal band and dark brown sutural area (Fig. 55). Median lobe and parameres of the aedeagus short, robust, roundish (Figs 65-66)

F. pastazensis sp.n.

- Elytra only with dark brown postdiscal band (Fig. 56) Median lobe and parameres of the aedeagus elongate, relatively narrow (Figs 68-69) .... F. tiputiniensis sp.n.

\section{Flabellocaenia iquitosensis Kazantsev, sp.n.} Figs 53, 57-59.

MATERIAL: Holotype, $0^{7}$, Peru: Loreto, $80 \mathrm{~km}$ NE Iquitos, rain forest, FIT, $120 \mathrm{~m}, 10-14 . I X .2015$ A. Petrov leg. (ICM); paratypes: $6 \mathrm{O}^{7} \mathrm{O}^{7}$, same label (ICM)

DESCRIPTION. Male. Dark brown to black; antennomeres $2-3$, stems of antennomeres $4-7$, apices of antennal flabellae, elytra at shoulders, coxae, trochanters, femoris proximally and distally, tibiae proximally and ultimate abdominal segments testaceous (Fig. 53).

Vertex shining, finely punctate, with short narrow median keel and a pair of small round impressions at its sides just behind antennal prominence and longitudinal bulge posteriorly. Eyes relatively small, interocular distance ca. 1.4 times greater than eye diameter. Palps miniature, tapering distally. Antennal sockets separated by minute lamina. Antennae from antennomere 4 flabellate, attaining to elytral half; flabellum of antennomere 4 ca. 19 times, flabellum of antennomere 5 ca. 13.5 times, flabellum of antennomere 6 ca. 7.7 times longer than relative stems; stem of antennomere $4 \mathrm{ca}$. sub- equal in length to antennomeres 2 and 3 and ca. 2 times shorter than stem of antennomere 5; antennomeres 4-11 with very short sub-erect pubescence (Fig. 53).

Pronotum transverse, ca. 1.7 times as wide as long, trapezoidal, with slightly convex sides, conspicuously bisinuate basally and almost straight anteriorly, with small acute posterior and blunt anterior angles; median rib with narrow groove. Mesothoracic spiracle noticeably protruding, distally turned backwards. Scutellum transverse, narrowing distally, emarginate at apex (Fig. 53).

Elytra narrow, long, ca. 3.8 times longer than wide at humeri, almost parallel-sided, strongly dehiscent in posterior three fourths, with conspicuous primary costae 1,2 and 4, costa 1 developed in proximal two thirds; all interstices finely granulose; pubescence short and semi-erect (Fig. 53). Femoris and tibiae straight, narrow; tarsomeres narrow, without plantar pad.

Paraproct not divided by median suture; ultimate ventrite (sternite 9) with parallel-sided spiculum gastrale (Fig. 57). Aedeagus with relatively robust oval parameres and median lobe; phallobase medially not divided by suture, attaining to ca. 0.6 length of median lobe (Figs 58-59).

Female. Unknown.

Length: 4.6-5.7 mm. Width (humerally): $1.0-1.3 \mathrm{~mm}$.

ETYMOLOGY. The new species is named after the locality where the type specimens were collected.

DIAGNOSIS. Flabellocaenia iquitosensis sp.n. is separable from the congeners with long flabellum of antennomere 4 by the dark brown, with testaceous bases elytra (Fig. 53) and elongate and oval aedeagus (Figs 58-59).

DISTRIBUTION. Amazon basin, Peru.

\section{Flabellocaenia ocopensis Kazantsev, sp.n.} Figs 54, 60-62.

MATERIAL: Holotype, $0^{7}$, Peru: Junin (Satipo), Rio Perene, 15 km NE Puerto Ocopa, Sta Cruz, 1100 m, 8.I.2007, A. Petrov leg. (ICM).

DESCRIPTION. Male. Dark brown to black; antennomere 11, apices of flabellae of antennomeres 5-10, elytra at proximal third and distal fifth, metaventrite medially, coxae, trochanters femoris proximally and knees testaceous (Fig. 54).

Vertex shining, finely punctate, with long narrow median keel and roundish impression behind antennal prominence. Eyes relatively small, bulging, interocular distance ca. 1.5 times greater than eye diameter. Palps miniature, tapering distally. Antennal sockets separated by minute lamina. Antennae from antennomere 4 flabellate, attaining to elytral two fifths; flabellum of antennomere $4 \mathrm{ca} .3$ times, flabellum of antennomere $5 \mathrm{ca}$. 2.4 times, flabellum of antennomere $6 \mathrm{ca}$. 3.2 times longer than relative stems; stem of antennomere 4 ca. 1.6 times longer than antennomeres 2 and 3 combined and ca. 1.4 times shorter than stem of antennomere 5; antennomeres 4-11 with very short decumbent pubescence and small roundish scales (Fig. 54).

Pronotum transverse, ca. 1.9 times as wide as long, trapezoidal, with slightly concave sides, bisinuate basally and triangularly produced anteriorly, with prominent acute posterior and blunt anterior angles; median rib grooved in posterior half. Mesothoracic spiracle small, hardly protruding beyond coxa. Scutellum transverse, narrowing distally, slightly emarginate at apex (Fig. 54)

Elytra narrow, long, ca. 3.7 times longer than wide at humeri, almost parallel-sided, conspicuously dehiscent in posterior three fourths, with developed primary costae 1,2 and 4 , costa 1 present in proximal two thirds; all interstices finely granulose; pubescence short and semi-erect (Fig. 54). 


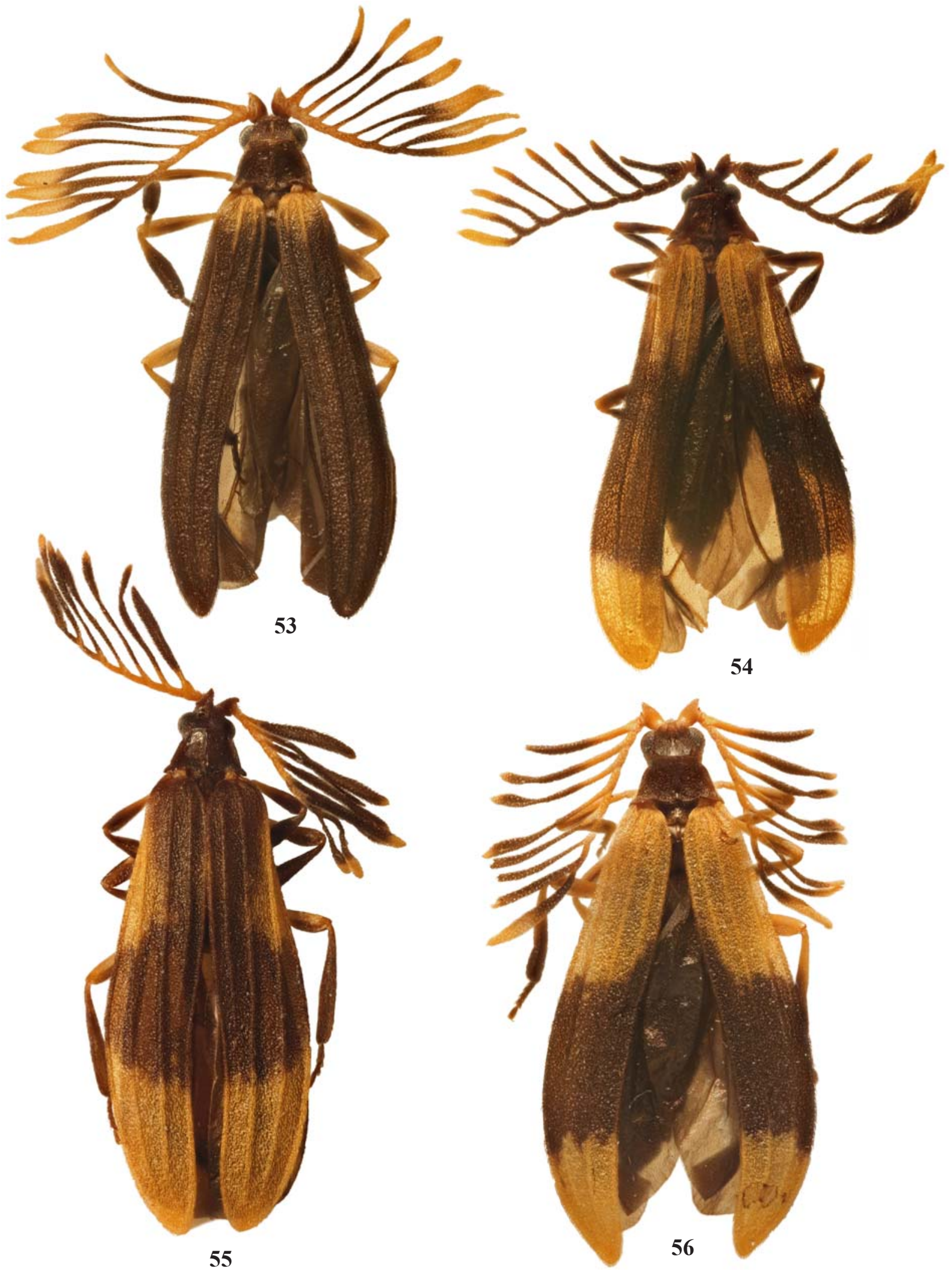

Figs 53-56. General view of Flabellocaenia, male holotypes: $53-$ F. iquitosensis sp.n.; $54-F$. ocopensis sp.n.; $55-F$. pastazensis sp.n.; $56-F$. tiputiniensis sp.n.

Рис. 53-56. Общий вид Flabellocaenia, голотипы, самцы: $53-$ F. iquitosensis sp.n.; $54-F$. ocopensis sp.n.; 55 - F. pastazensis sp.n.; $56-F$. tiputiniensis sp.n. 
Femoris and tibiae straight, narrow; tarsomeres narrow, without plantar pad.

Paraproct not divided by median suture; ultimate ventrite (sternite 9) with short narrowed proximally spiculum gastrale (Fig. 60). Aedeagus with relatively narrow, somewhat constricted distally parameres and relatively narrow median lobe; phallobase medially not divided by suture, attaining to ca. 0.5 length of median lobe (Figs 61-62).

Female. Unknown.

Length: $5.2 \mathrm{~mm}$. Width (humerally): $1.2 \mathrm{~mm}$.

ETYMOLOGY. The new species is named after the locality where the type specimen was collected.

DIAGNOSIS. Flabellocaenia ocopensis sp.n. is easily separable from the congeners by the relatively long stem of antennomere 4 whose flabellum is only ca. 3 times longer than stem itself and relatively short flabellae of subsequent antennomeres (Fig. 54), as well as by the oval and constricted distally parameres of the aedeagus (Figs 61-62).

DISTRIBUTION. Peru.

\section{Flabellocaenia pastazensis Kazantsev, sp.n. Figs 55, 63-66.}

MATERIAL: Holotype, $\sigma^{7}$, Ecuador: Pastaza, Rd E45, intersection with Rio Pastaza, 800 m, 29.VI.2016, S. \& S. Kazantsev leg. (ICM).

DESCRIPTION. Male. Dark brown to black; antennomeres 2-3, stems of antennomeres 4-8, apex of antennomere 11 and apices and bases of flabellae of antennomeres 5-10, elytra at proximal two fifths laterally and at distal third, trochanters and femoris proximally testaceous (Fig. 55).

Vertex shining, finely punctate, with short narrow median keel and a pair of small round impressions at its sides just behind antennal prominence and longitudinal bulge posteriorly. Eyes relatively small, interocular distance ca. 1.3 times greater than eye diameter. Labrum small, transverse, straight anteriorly. Palps miniature, tapering distally. Antennal sockets separated by minute lamina. Antennae from antennomere 4 flabellate, attaining to elytral half; flabellum of antennomere $4 \mathrm{ca} .12$ times, flabellum of antennomere 5 ca. 9 times, flabellum of antennomere $6 \mathrm{ca}$. 7.7 times longer than relative stems; stem of antennomere $4 \mathrm{ca}$. subequal in length to antennomeres 2 and 3 combined and ca. 1.5 times shorter than stem of antennomere 5; antennomeres 3-11 with short sub-erect pubescence (Fig. 55).

Pronotum transverse, ca. 1.8 times as wide as long, trapezoidal, with straight sides, conspicuously bisinuate basally and roundish anteriorly, with small acute posterior and blunt anterior angles; median rib with narrow groove in posterior half. Mesothoracic spiracle noticeably protruding, distally turned backwards. Scutellum transverse, almost parallel-sided, emarginate at apex (Fig. 55).

Elytra narrow, long, ca. 3.75 times longer than wide at humeri, almost parallel-sided, dehiscent in posterior two thirds, with conspicuous primary costae 1,2 and 4, costa 1 developed in proximal three fifths; all interstices finely granulose; pubescence dense, short and decumbent (Fig. 55) Femoris and tibiae straight, narrow; tarsomeres narrow, without plantar pad.

Paraproct not divided by median suture (Fig. 63); ultimate ventrite (sternite 9) with parallel-sided spiculum gastrale (Fig. 64). Aedeagus with relatively short, robust and roundish parameres and median lobe; phallobase medially not divided by suture, attaining to ca. 0.65 length of median lobe (Figs 65-66).

Female. Unknown.

Length: $6.9 \mathrm{~mm}$. Width (humerally): $1.5 \mathrm{~mm}$.

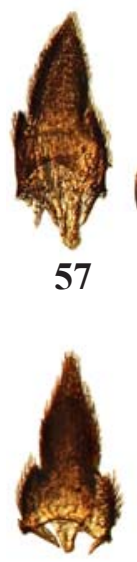

60

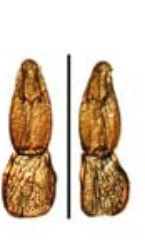

5859

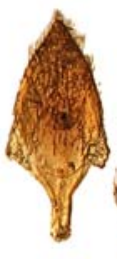

64
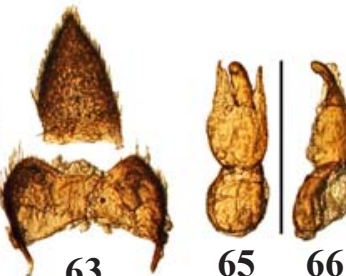

$65 \quad 66$

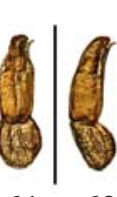

6162

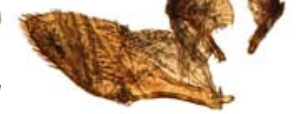

67

Figs 57-69. Details of Flabellocaenia, male holotypes: 57-59$F$. iquitosensis sp.n.; 60-62 - F. ocopensis sp.n.; 63-66-F. pastazensis sp.n.; 67-69 - F. tiputiniensis sp.n.; 57, 60, 63-64, 67 - ultimate abdominal segments; 58-59, 61-62, 65-66, 68-69aedeagus; $57-58,60-61,64-65,67-68$ - dorsally; 63 - ventrally; 59, 62, 66, 69 - laterally. Scales: $0.5 \mathrm{~mm}$.

Рис. 57-69. Детали строения Flabellocaenia, голотипы, самцы: 57-59-F. iquitosensis sp.n.; 60-62-F. ocopensis sp.n.; 63-66 - F. pastazensis sp.n.; 67-69-F. tiputiniensis sp.n.; 57, 60, 63-64, 67 - вершинные сегменты брюшка; 58-59, 61-62, 65-66, 68-69 - эдеагус; 57-58, 60-61, 64-65, 67-68 - сверху; 63 - снизу; 59, 62, 66, 69 - сбоку. Масштабные линейки: 0,5 мм.

ETYMOLOGY. The new species is named after the province where the type specimen was collected.

DIAGNOSIS. Flabellocaenia pastazensis sp.n. is separable from the congeners with the larger size, long flabellum of antennomere 4 by the coloration, with dark dark brown sutural elytral area (Fig. 55), shape of pronotum and short, robust and roundish median lobe and parameres of the aedeagus (Figs 65-66).

\section{DISTRIBUTION. Ecuador.}

\section{Flabellocaenia tiputiniensis Kazantsev, sp.n.} Figs 56, 67-69.

MATERIAL: Holotype, $\sigma^{7}$, Ecuador: Orellana, Tiputini Bio. Stn., $0^{\circ} 39.5^{\prime} \mathrm{S}, 7^{\circ} 26^{\prime} \mathrm{W}$, FIT, 28.VII-3.VIII.2008, A. Tishechkin leg. (ICM)

DESCRIPTION. Male. Dark brown to black; antennomeres 1-3, antennomere 11 in distal half, stems of antennomeres 4-9, apices of flabellae of antennomeres 5-10, elytra, except broad postdiscal band, coxae, trochanters and femoris and tibiae proximally testaceous (Fig. 56).

Vertex shining, finely punctate, with short narrow median keel and a pair of small round impressions at its sides just behind antennal prominence and obscure longitudinal bulge posteriorly. Eyes small, flattened, interocular distance ca. 1.4 times greater than eye diameter. Palps miniature, tapering distally. Antennal sockets separated by minute lamina. Antennae from antennomere 4 flabellate, attaining almost to elytral half; flabellum of antennomere 4 ca. 15 times, flabellum of antennomere $5 \mathrm{ca}$. 8.5 times, flabellum of antennomere $6 \mathrm{ca}$. 6.7 times longer than relative stems; stem of antennomere $4 \mathrm{ca}$. 1.6 times shorter than antennomeres 2 and 3 combined and ca. 2.5 times shorter than stem of antennomere 5; antennomeres 3 11 with short decumbent pubescence (Fig. 56).

Pronotum transverse, ca. 2 times as wide as long, trapezoidal, with straight sides, bisinuate basally and almost straight 
anteriorly, with small acute posterior and blunt anterior angles; median rib with narrow groove. Mesothoracic spiracle noticeably protruding, distally straight. Scutellum transverse, almost parallel-sided, emarginate at apex (Fig. 56).

Elytra narrow, long, ca. 3.4 times longer than wide at humeri, almost parallel-sided, dehiscent in posterior three fourths, with conspicuous primary costae 1,2 and 4 , costa 1 developed in proximal two thirds; all interstices finely granulose; pubescence short and semi-erect (Fig. 56). Femoris and tibiae straight, narrow; tarsomeres narrow, without plantar pad.

Paraproct not divided by median suture; ultimate ventrite (sternite 9) with parallel-sided spiculum gastrale (Fig. 67). Aedeagus with elongate, relatively narrow parameres and median lobe; phallobase medially not divided by suture, attaining to ca. 0.6 length of median lobe (Figs 68-69).

Female. Unknown.

Length: $5.6 \mathrm{~mm}$. Width (humerally): $1.2 \mathrm{~mm}$.

ETYMOLOGY. The new species is named after the locality where the type specimen was collected.

DIAGNOSIS. Flabellocaenia tiputiniensis sp.n. is separable from the congeners with the long flabellum of antennomere 4 by the coloration, with only dark brown postdiscal band on the elytra (Fig. 56) and elongate, relatively narrow median lobe and parameres of the aedeagus (Figs 68-69).

DISTRIBUTION. Amazon basin, Ecuador.

Prioceraton Kazantsev, 2013

Prioceraton Kazantsev, 2013: 23.

type species (by monotypy) Ceratoprion ignavum Kazantsev, 2009.

REMARKS. So far a monotypic genus, with its type species described from Venezuela [Kazantsev, 2013]. Additional two species are described below.

DISTRIBUTION. Venezuela, Ecuador and Peru.

A key to species of Prioceraton Kazantsev, 2013 of ECUADOR AND PERU

1. Larger, over $6 \mathrm{~mm}$. Apex of median lobe of the aedeagus constricted, pointed; parameres short (Figs 72-73) ...... P. calabazense sp.n.

- Smaller, ca. $3.5 \mathrm{~mm}$. Apex of median lobe of the aedeagus widened, rounded; parameres elongate (Figs 76-77) .... P. tishechkini sp.n.

\section{Prioceraton calabazense Kazantsev, sp.n.}

Fig. 70-73.

MATERIAL: Holotype, ơ, Peru: Junin, Cordillera Or., Calabaza, $2300 \mathrm{~m}$, primary cloud forest, 10.III.2008, A. Petrov leg. (ICM).

DESCRIPTION. Male. Dark brown; ultimate antennomere yellowish.

Vertex finely and densely punctate, with conspicuous roundish impression behind antennal prominence, with short narrow median keel and a pair of longitudinal grooves at its sides in anterior third of the impression. Eyes small, interocular distance ca. 1.5 times greater than eye diameter. Maxillary palps miniature, tapering distally. Antennal sockets separated by minute lamina. Antennae attaining to elytral two fifths; from antennomere 4 flattened, almost parallel-sided; antennomeres 2 and 3 short, transverse, antennomere 4 ca. 2.2 times longer than antennomeres 2 and 3 combined and ca. 1.3 times longer than antennomere 5; antennal pubescence short, dense and decumbent (Fig. 70).

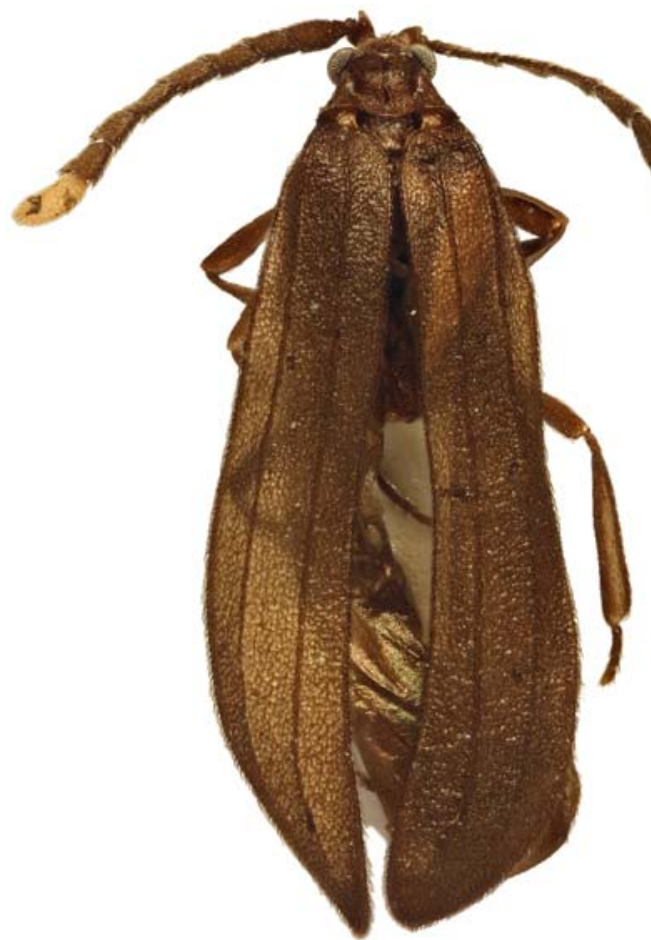

70

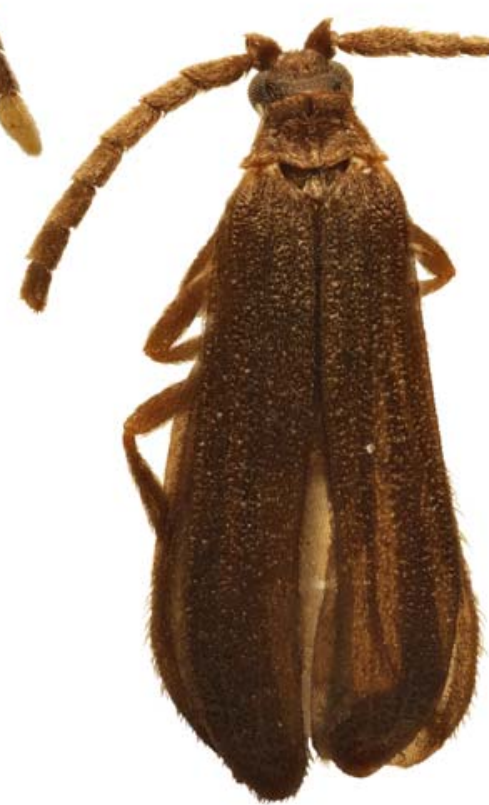

74
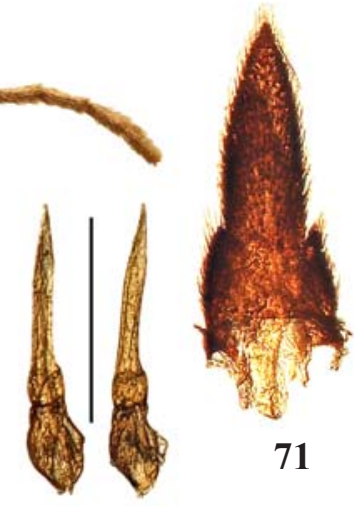

71
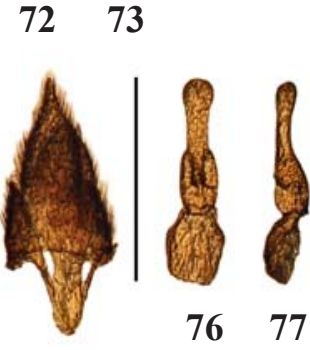

Figs 70-77. General view and details of Prioceraton, male holotypes: 70-73 - P. calabazense sp.n.; 74-77 - P. tishechkini sp.n.; 70, 74 - general view; 71, 75 — ultimate abdominal segments; 72-73, 76-77 — aedeagus; 70-72, 74-76 — dorsally; 73, 77 — laterally. Scales: 0.5 mm.

Рис. 70-77. Общий вид и детали строения Prioceraton, голотипы, самцы: 70-73 — P. calabazense sp.n.; 74-77 — P. tishechkini sp.n.; 70, 74 - общий вид; 71, 75 - вершинные сегменты брюшка; 72-73, 76-77 — эдеагус; 70-72, 74-76 — сверху; 73, 77 — сбоку. Масштабные линейки: 0,5 мм. 
Pronotum transverse, almost 2 times as wide as long, trapezoidal, with straight sides, conspicuously bisinuate basally and rounded anteriorly, with strongly produced lateroposteriorly pointed posterior and rounded anterior angles; median rib bifurcate in posterior two fifths (Fig. 70). Mesothoracic spiracle small, simple, protruding beyond coxa. Scutellum transverse, slightly narrowing posteriorly, truncate at apex (Fig. 70).

Elytra long, ca. 3.6 times longer than wide at humeri, slightly widening distally, dehiscent in distal three fourths, with narrow, but distinct primary costae 2 and 4; interstices finely rugulose (Fig. 70). Trochanters long and narrow, metatrochanters only ca. 1.4 times shorter than femoris.

Paraproct not divided by median suture (Fig. 71). Aedeagus with narrow, pointed distally median lobe; parameres short, inconspicuous, attaining to ca. 0.25 of median lobe; phallobase without median suture, ca. 0.5 length of median lobe (Figs 72-73).

Female. Unknown.

Length: $6.3 \mathrm{~mm}$. Width (humerally): $1.5 \mathrm{~mm}$.

ETYMOLOGY. The new species is named after the locality where the type specimen was collected.

DIAGNOSIS. Prioceraton calabazense sp.n. can be separated from P. ignavum (Kazantsev, 2009) by the dark brown pronotum and different structure of the aedeagus (Figs 70 73). It may be distinguished from $P$. tishechkini sp.n. by the larger size and narrow, pointed apically median lobe of the aedeagus.

DISTRIBUTION. Known only from Peru.

\section{Prioceraton tishechkini Kazantsev, sp.n.}

Fig. 74-77.

MATERIAL: Holotype, $\sigma^{7}$, Ecuador: Orellana, Yasuni N.P., Via Maxus at Qued, Pirana Bridge, $0^{\circ} 39.5^{\prime} \mathrm{S}, 76^{\circ} 26^{\prime} \mathrm{W}, \mathrm{FIT}, 14$ 24.VII.2008, A. Tishechkin leg. (ICM); paratype, O', same label (ICM).

DESCRIPTION. Male. Dark brown; trochanters and very bases of femoris testaceous.

Vertex finely punctate, with conspicuous transverse impression behind antennal prominence, with short narrow median keel and a pair of longitudinal grooves at its sides anteriorly. Eyes small, interocular distance ca. 1.5 times greater than eye diameter. Maxillary palps miniature, tapering and pointed distally. Antennal sockets separated by minute lamina. Antennae attaining to ca. elytral two fifths; from antennomere 4 flattened, almost parallel-sided; antennomeres 2 and 3 short, transverse, antennomere 4 ca. 2.3 times longer than antennomeres 2 and 3 combined and ca. 1.1 times longer than antennomere 5; antennal pubescence short, dense and decumbent (Fig. 74).

Pronotum transverse, almost 2 times as wide as long, trapezoidal, with nearly straight sides, conspicuously bisinuate basally and almost straight anteriorly, with strongly produced latero-posteriorly posterior and blunt anterior angles; median rib obscurely bifurcate in posterior half (Fig. 74) Mesothoracic spiracle simple, conspicuously protruding beyond coxa. Scutellum transverse, slightly narrowing posteriorly, truncate at apex (Fig. 74).

Elytra long, ca. 3.9 times longer than wide at humeri, slightly widening distally, dehiscent in distal two thirds, with distinct primary costae 2 and 4 , with costa 1 noticeable in proximal half; interstices finely rugulose (Fig. 74). Trochanters long and narrow, metatrochanters only ca. 1.6 times shorter than femoris.

Paraproct not divided by median suture; spiculum gastrale almost parallel-sided and rounded proximally (Fig. 75).
Aedeagus with relatively short, widened and rounded distally median lobe; parameres elongate, conspicuous, attaining to ca. 0.5 of median lobe; phallobase without median suture, ca. 0.5 length of median lobe (Figs 76-77).

Female. Unknown.

Length: 3.3-3.6 mm. Width (humerally): $0.7-0.8 \mathrm{~mm}$.

ETYMOLOGY. The species is named after Dr. Aleksey Tishechkin (Santa Barbara, California, USA), who collected its type series.

DIAGNOSIS. Prioceraton tishechkini sp.n. resembles $P$. calabazense sp.n., but is smaller (Fig. 74), the apex of the median lobe of its aedeagus is widened and rounded; parameres elongate (Figs 76-77).

REMARKS. Tips of antennae (antennomeres 11) in both type specimens are missing.

DISTRIBUTION. Known only from Ecuador.

Pseudacroleptus Pic, 1911

\section{Pseudacroleptus Pic, 1911.}

type species Pseudacroleptus obscuricolor Pic, 1911.

Flabellolycinella Kleine, 1941: 303, syn.n. 1941.

type species (by monotypy) Flabellolycinella crocea Kleine,

REMARKS. In all characters the genus Flabellolycinella agrees with Pseudacroleptus Pic, 1911. In his paper Kleine does not compare the new taxon with Pseudacroleptus, instead, comparing it with Lycinella Gorham, 1884 [Kleine, 1941]. Therefore, Flabellolycinella Kleine, 1941, syn.n. is considered to be a junior synonym of Pseudacroleptus Pic, 1911.

So far five species, including Pseudacroleptus croceus (Kleine, 1941), have been known in the genus, two of them reported from Peru [Kleine, 1933; 1941; Kazantsev, Zaitsev, 2009; Kazantsev, 2013]. Additional two species are described below.

DISTRIBUTION. Brazil, French Guyana, Venezuela, Ecuador and Peru.

A key to species of PSEudacroleptus Pic, 1911 of EcuaDOR AND PERU

1. Eyes distinctly larger, bulging, interocular distance subequal in length to eye diameter (Fig. 83) ...

\section{P. orellanus sp.n.}

- Eyes smaller, flattened, interocular distance noticeably smaller than eye diameter (e.g., Figs 78, 82) ............. 2

2. Elytra uniformly dark brown (Fig. 78). Constricted distal portion of median lobe of aedeagus distinctly longer than parameres (Figs 80-81) ................. P. aleksandri sp.n.

- Elytra mostly orange testaceous (e.g., Fig. 82). Constricted distal portion of median lobe of aedeagus shorter than basis

3. Legs, including tarsi, uniformly orange testaceous (Fig. 82) .............................. P. gorgonus Kazantsev, 2013 - Bases of femoris and tarsi brown

P. croceus (Kleine, 1941)

Pseudacroleptus aleksandri Kazantsev, sp.n. Figs 78-81.

MATERIAL: Holotype, $\sigma^{7}$, Peru: Loreto, Rio Amazon, 58-68 $\mathrm{km}$ SSW Iquitos (to Nauta), $4^{\circ} 15^{\prime} \mathrm{S}, 73^{\circ} 28^{\prime} \mathrm{W}, 120-140 \mathrm{~m}$, primary rainforest, FIT, 20-24.IX.2015, A. Petrov leg. (ICM).

DESCRIPTION. Male. Orange testaceous; medial part of antennal flabellae and antennomere 11 and elytra dark brown to black.

Vertex shining, finely punctate, with shallow transverse impression and small narrow median keel just behind antennal prominence. Eyes relatively small, flattened, interocular 


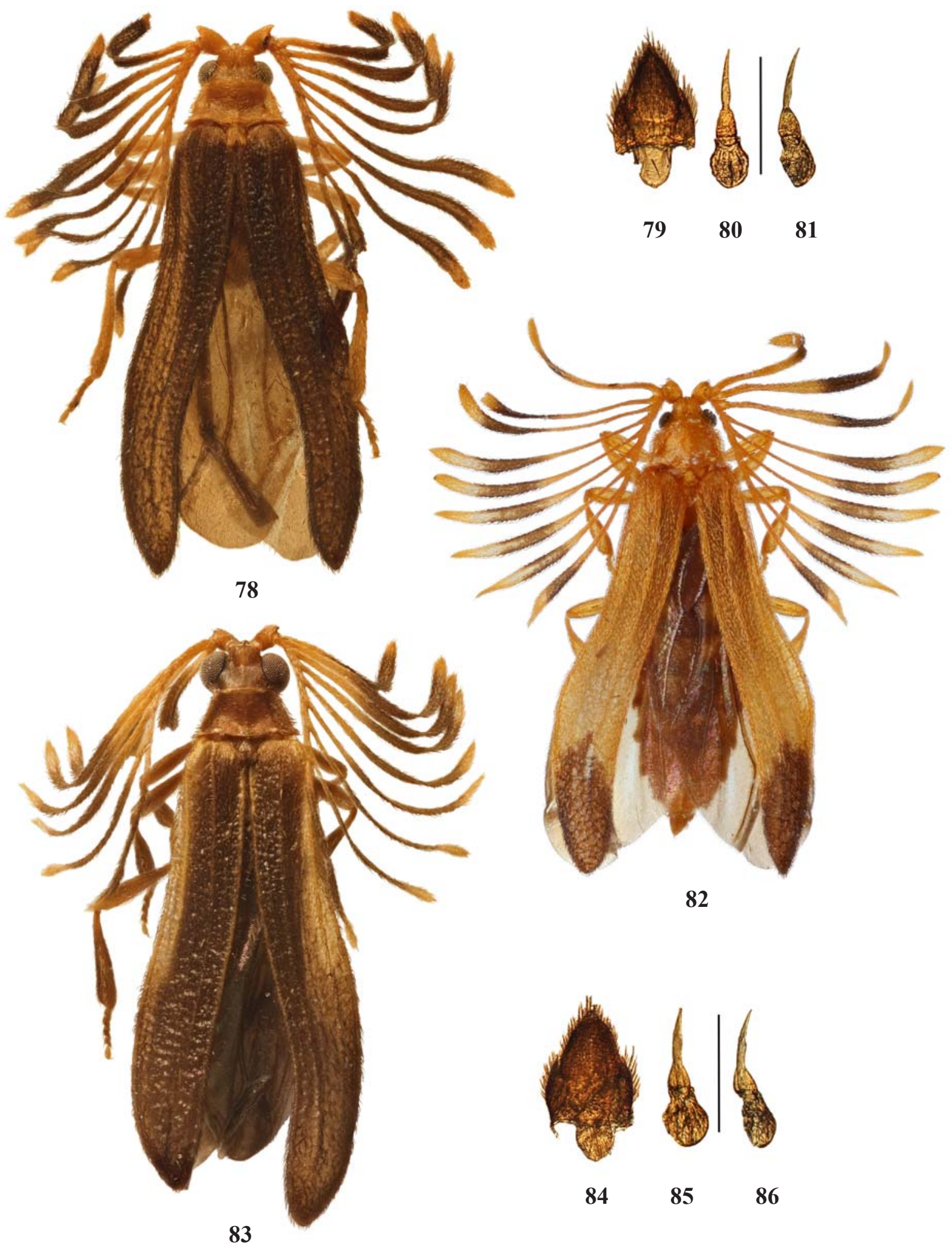

Figs 78-86. General view and details of Pseudacroleptus, male holotypes: 78-81 - P. aleksandri sp.n.; $82-$ P. gorgonus; 83-86 P. orellanus sp.n.; 78, 82-83 - general view; 79, 84 - ultimate abdominal segments; 80-81, 85-86 — aedeagus; 78-80, 82-85 - dorsally; 81,86 - laterally. Scales: $0.5 \mathrm{~mm}$.

Рис. 78-86. Общий вид и детали строения Pseudacroleptus, голотипы, самцы: 78-81 - P. aleksandri sp.n.; 82 - P. gorgonus; 8386 - P. orellanus sp.n.; 78, 82-83 - общий вид; 79, 84 - вершинные сегменты брюшка; 80-81, 85-86 - эдеагус; 78-80, 82-85 сверху; 81, 86 - сбоку. Масштабные линейки: 0,5 мм. 
distance ca. 1.4 times greater than eye diameter. Maxillary palps slender, ultimate palpomeres elongate, narrow, pointed distally. Antennal sockets separated by minute lamina. Antennae flabellate, attaining to elytral half; flabellae of antennomeres $3-5$ ca. 20 times longer than relative stems; stem of antennomere 3 subequal in length to antennomere 2 and ca. 1.5 times shorter than antennomere 4; antennomeres 3-11 with short sub-erect pubescence (Fig. 78).

Pronotum transverse, ca. 2.2 times as wide as long, trapezoidal, with nearly straight sides, bisinuate basally and almost straight anteriorly, with small acute posterior and blunt anterior angles; medially with obscure areole in posterior two thirds (Fig. 78). Mesothoracic spiracle noticeably protruding. Scutellum subquadrate, parallel-sided, deeply emarginate at apex (Fig. 78).

Elytra long, ca. 3.7 times longer than wide at humeri, widening distally, conspicuously dehiscent in distal three thirds, with distinct primary costae 2 and 4 ; interstices roughly rugulose (Fig. 78).

Paraproct not divided by median suture; spiculum gastrale short and rounded proximally (Fig. 79). Aedeagus with narrow, straight, pointed apically and constricted at the middle median lobe; parameres elongate, conspicuously wider than median lobe, attaining to ca. 0.35 of median lobe; phallobase with median suture, ca. 0.4 length of median lobe (Figs 80-81).

Female. Unknown.

Length: $5.1 \mathrm{~mm}$. Width (humerally): $1.2 \mathrm{~mm}$.

ETYMOLOGY. The species is named after Dr. Aleksander Petrov (Moscow), who has contributed greatly to the Insect Centre Neotropical Lycidae collection.

DIAGNOSIS. Pseudacroleptus aleksandri sp.n. is separable from the congeners by the uniformly dark brown elytra and Constricted distal portion of median lobe of aedeagus distinctly longer than basis (Figs 78-81)

DISTRIBUTION. Amazon basin, Peru.

\section{Pseudacroleptus orellanus Kazantsev, sp.n. Figs 83-86.}

MATERIAL: Holotype, $\sigma^{\top}$, Ecuador: Orellana, Tiputini Bio. Stn., $0^{\circ} 39.5^{\prime} \mathrm{S}, 7^{\circ} 26^{\prime} \mathrm{W}$, FIT, 28.VII-3.VIII.2008, A. Tishechkin leg. (ICM); paratype, $\sigma^{7}$, same label; $\sigma^{7}$, Ecuador: Orellana, Yasuni Res. Stn., $0^{\circ} 39.5^{\prime} \mathrm{S}, 76^{\circ} 26^{\prime} \mathrm{W}$, FIT, 11-26.VII.2008, A. Tishechkin leg. (ICM).

DESCRIPTION. Male. Dark brown; antennae, except medial part of flabellae and antennomere 11 , elytral bases and sides at proximal two thirds, coxae, trochanters and ultimate tarsomere testaceous.

Vertex shining, glabrous, with shallow transverse impression and inconspicuous narrow median keel just behind antennal prominence. Eyes relatively large, interocular distance subequal in length to eye diameter. Palps slender, tapering, ultimate palpomeres pointed distally. Antennal sockets separated by minute lamina. Antennae flabellate, attaining to elytral half; flabellae of antennomeres 3-5 ca. 20 times longer than relative stems; stem of antennomere 3 subequal in length to antennomere 2 and ca. 1.5 times shorter than antennomere 4; antennomeres 3-11 with short sub-erect pubescence (Fig. 83).

Pronotum transverse, ca. 2.1 times as wide as long, trapezoidal, with straight sides, inconspicuously bisinuate basally and almost straight anteriorly, with small acute posterior and blunt anterior angles; medially without distinct structures (Fig. 83). Mesothoracic spiracle noticeably protruding. Scutellum elongate, subparallel-sided, deeply emarginate at apex (Fig. 83).

Elytra long, ca. 3.8 times longer than wide at humeri, widening distally, conspicuously dehiscent in distal three thirds, with distinct primary costae 2 and 4 ; interstices roughly rugulose (Fig. 83).

Paraproct not divided by median suture; spiculum gastrale short and rounded proximally (Fig. 84). Aedeagus with straight, narrowed near apex and not constricted at the middle median lobe; parameres oval, conspicuously wider than median lobe, attaining to ca. 0.35 of median lobe; phallobase with median suture, ca. 0.5 length of median lobe (Figs 85-86).

Female. Unknown.

Length: $5.3-6.0 \mathrm{~mm}$. Width (humerally): $1.2-1.3 \mathrm{~mm}$.

ETYMOLOGY. The new species is named after the province where two of the three type specimens were collected.

DIAGNOSIS. Pseudacroleptus orellanus sp.n. is easily distinguished from the congeners by the distinctly larger eyes, with their interocular distance subequal in length to eye diameter (Fig. 83); it may additionally be separated from $P$. aleksandri sp.n. by the coloration and not constricted at the middle median lobe of the aedeagus with more oval parameres and longer phallobase (Figs 85-86).

DISTRIBUTION. Amazon basin, Peru.

\section{Tishechkinia Kazantsev, 2013}

Tishechkinia Kazantsev, 2013: 12. 2005

type species (by monotypy) Neolyrium carltoni Kazantsev,

REMARKS. Until now a monotypic genus, its type species described from Ecuador [Kazantsev, 2005]. One additional species has been discovered in the Peru material.

DISTRIBUTION. Ecuador and Peru.

A key to species of TishechKinia KaZantsev, 2013 of ECUADOR AND Peru

1. Body uniformly dark brown, except yellow ultimate antennomere. Medial antennomeres slightly elongate (Fig. 87) (Ecuador) ................ T. carltoni (Kazantsev, 2005)

- Pronotum and bases of elytra testaceous, antennomere 3 light brown, ultimate antennomere dark brown. Medial antennomeres subquadrate (Fig. 88) (Peru) ...

T. petrovi sp.n.

\section{Tishechkinia petrovi Kazantsev, sp.n.} Fig. 88.

MATERIAL: Holotype, $0^{7}$, Peru: Junin, Cordillera Or., Rio Perene, 8 km NNE Pto Ocope, Cananeden, $11^{\circ} 06^{\prime} \mathrm{S}, 73^{\circ} 50^{\prime} \mathrm{W}, 1100$ $\mathrm{m}$, primary montane rainforest, 27.III.2009, A. Petrov leg. (ICM).

DESCRIPTION. Male. Light brown to orange brown; head, antennae and elytra, except at bases, dark brown.

Vertex finely punctate behind antennal prominence, with shallow transverse impression and narrow median keel between eyes. Eyes small, interocular distance ca. 1.5 times greater than eye diameter, flattened. Antennal sockets separated by minute lamina. Antennae attaining to elytral two thirds, from antennomere 3 conspicuously widened; antennomeres 3-10 almost parallel-sided; antennomere 3 ca. 18 times longer than antennomere 2 and ca. 1.25 times longer than antennomere 4 (Fig. 88).

Pronotum transverse, almost 2.3 times as wide as long, trapezoidal, with almost straight sides, slightly bisinuate basally and somewhat rounded anteriorly, with strongly produced latero-posteriorly posterior and blunt rounded anterior angles; median keel narrow, narrowly bifurcate in posterior half. Scutellum transverse, parallel-sided, truncate at apex (Fig. 88).

Elytra narrow, long, ca. 3.2 times longer than wide at humeri, slightly widening distally, dehiscent in distal two thirds, with obscure weak primary costae 2 and 4, densely and roughly granulose (Fig. 88). 

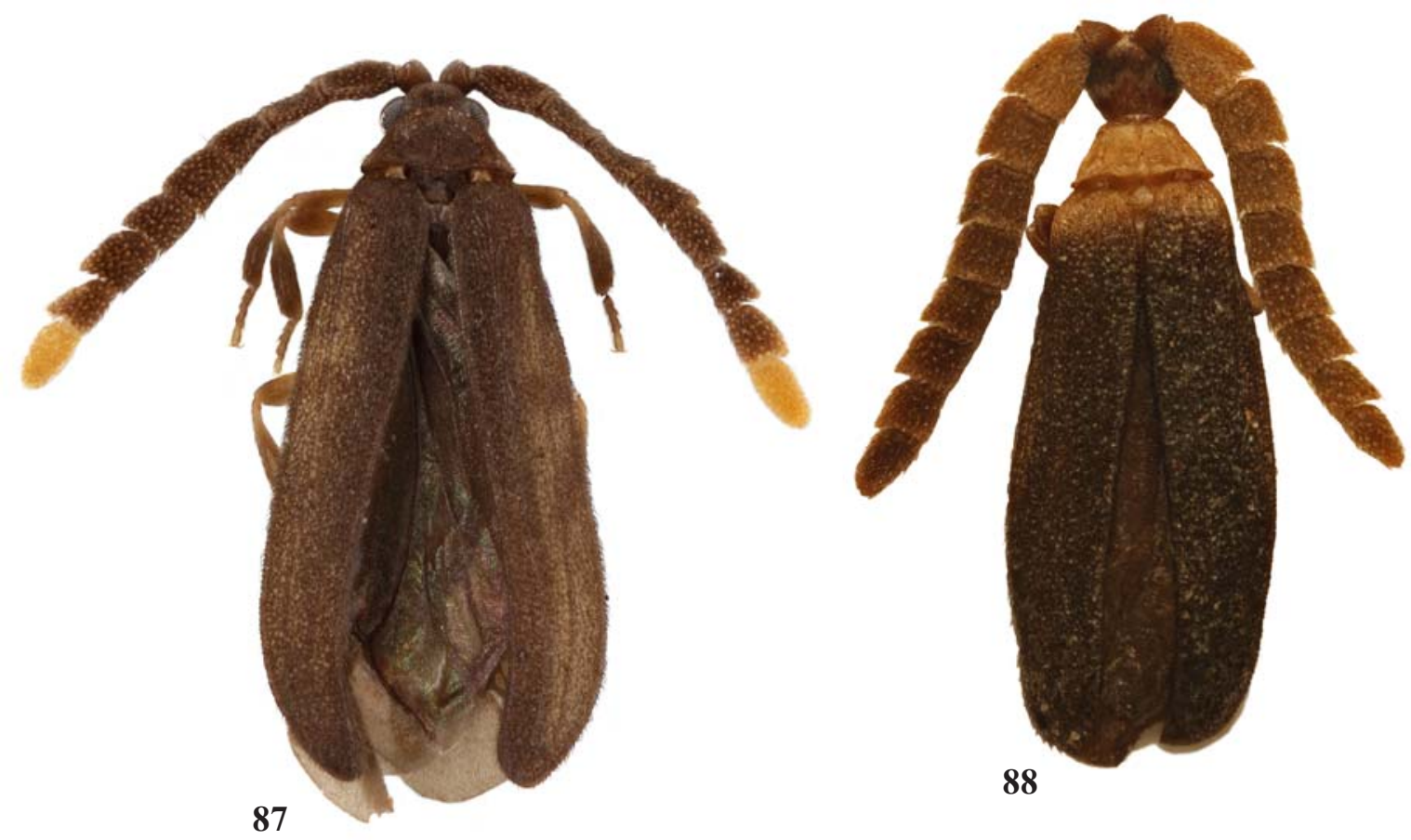

Figs 87-88. General view of Tishechkinia, males: $87-T$. carltoni, paratype; $88-T$. petrovi sp.n., holotype.

Рис. 87-88. Общий вид Tishechkinia, самцы: $87-$ T. carltoni, паратип; $88-$ T. petrovi sp.n., голотип.

Female. Unknown.

Length: $3.4 \mathrm{~mm}$. Width (humerally): $0.8 \mathrm{~mm}$.

ETYMOLOGY. The species is named after Dr. Aleksander Petrov (Moscow), whose 1999 and 2005-2015 collecting trips to Peru have added considerably to the Insect Centre Neotropical Lycidae collection.

DIAGNOSIS. Tishechkinia petrovi sp.n. can be separated from T. carltoni (Kazantsev, 2013), the only other known species of the genus, by the coloration and conspicuously more quadrate medial antennomeres (Fig. 88).

REMARKS. The tip of abdomen in the type specimen is missing.

DISTRIBUTION. Known only from Peru.

ACKNOWLEDGEMENTS. It is my pleasant duty to express gratitude to Dr. C. Carlton and Dr. V. Bayless (LSAM) through whose courtesy I was able to study the Lycidae collection under their care, to Dr. Alexander Petrov (Moscow) and Dr. Aleksey Tishechkin (Santa Barbara, California) for handing over extensive lycid material collected during their entomological expeditions to Ecuador and Peru. My special thanks are due to Prof. Kirill Makarov (Moscow) for his kind help with some of the colour photos (Figs 2-3, 5$6,15,27)$.

\section{References}

Bocák L. 2001. New taxa of Leptolycus (Coleoptera: Lycidae) from the Dominican Republic // Folia Heyrovskyana. Vol.9. Nos.34. P.203-210.

Blackwelder R.E. 1945. Checklist of the Coleopterous insects of Mexico, Central America, the West Indies, and South America.
Part 3. Superfamily Cantharoidea // Bulletin of the US National Museum. Vol.185. P.343-550.

Constantin R. 2010. Les genres de Cantharidae, Lampyridae, Lycidae et Telegeusidae de Guyane française (Coleoptera, Elateroidea) // Contribution à l'étude des Coléoptères de Guyane. T.2. P.32-45.

Ferreira V.S., Ivie M.A. 2016. Redescription of Cephalolycus major Pic, 1926 (Coleoptera: Elateroidea: Lycidae) and a Discussion on its Taxonomic Position // The Coleopterists Bulletin. Vol.70. No.3. P.663-666.

Kazantsev S.V. 2005. Neolyrium gen. n., first South American genus of net-winged beetles with 10-segmented antennae (Coleoptera: Lycidae) // Zootaxa. Vol.1064. P.51-64.

Kazantsev S.V. 2009. Leptolycini of Puerto Rico (Coleoptera, Lycidae) // Russian Entomological Journal. Vol.18. No.2. P.8795.

Kazantsev S.V. 2012. A new lycid genus from the Dominican Amber (Insecta, Coleoptera, Lycidae, Leptolycinae, Leptolycini) // Psyche. Vol.2012. P.1-3.

Kazantsev S.V. 2013. New and little known taxa of "neotenic" Lycidae (Coleoptera), with discussion of their phylogeny // Russian Entomological Journal. Vol.2. No.1. P.9-31.

Kazantsev S.V., Zaitsev A.A. 2009. Description of larval and imaginal stages of new species from the genera Pseudacroleptus Pic, 1911 and Ceratoprion Gorham, 1880 (Coleoptera: Lycidae: Leptolycinae) // Russian Entomological Journal. Vol.17. No.3 (2008). P.283-292.

Kleine R. 1933. Pars 123: Lycidae // Coleopterorum Catalogus auspiciis et auxilio W. Junk editus a Schenkling. Berlin: W. Junk. 145 pp.

Kleine R. 1941. Lycidae (Col.) // Beiträge zur Fauna Perus. B.1. S.295-306

Miller R.S. 1991. A revision of Leptolycini (Coleoptera: Lycidae) with a discussion of paedomorphosis. PhD Dissertation. The Ohio State University. 403 pp. (unpublished).

Nascimento E.A. do, Bocakova M. 2009. A revision of the genus Lycomorphon (Coleoptera: Lycidae) // Zootaxa. Vol.2132. P.40-52. 